\title{
A TUTELA JURÍDICA DO CICLO URBANO DA ÁGUA: linhas preliminares
}

\author{
THE LEGAL GUARANTEE OF THE URBAN WATER CYCLE: preliminary lines
}

\author{
José Irivaldo Alves Oliveira Silva ${ }^{1}$ \\ Talden Queiroz Farias ${ }^{2}$
}

\section{RESUMO}

O problema que ensejou o presente ensaio parte da necessidade de se tutelar a água no âmbito do seu ciclo urbano, o que preocupa bastante, na medida em que os países, incluindo-se o Brasil, são essencialmente urbanos. O objetivo do trabalho é justamente descrever o ciclo urbano da água, abordando de que forma ocorre a tutela jurídica do mesmo. 0 método utilizado foi o indutivo dedutivo, apoiado numa pesquisa bibliográfica e em dados secundários. Verifica-se que há uma fragilizada na tutela do ciclo urbano da água, certamente, por uma precária gestão e regulação dos recursos hídricos.

Palavras-chave: água; recursos hídricos; ciclo urbano da água; meio ambiente; complexidade.

\section{ABSTRACT}

The problem raised by this essay stems from the need to protect water within its urban cycle, which is of great concern, as countries, including Brazil, are essentially urban. The objective of this work is precisely to describe the urban water cycle, addressing how the legal protection of the water occurs. The method used was the deductive inductive, supported by bibliographic research and secondary data. It is verified that there is a weakened in the tutelage of the urban water cycle, certainly, by a precarious management and regulation of the water resources.

Keywords: water; water resources; urban water cycle; environment; complexity.

\footnotetext{
1 Pós-Doutor em Desenvolvimento Regional. Doutor em Ciências Sociais. Doutorando em Direito e Desenvolvimento. Pesquisador Produtividade do CNPq, nível 2. Em estágio Pós-doutoral no Programa de Pósgraduação em Direito, no Grupo de Pesquisa em Direito Ambiental e Sociedade de Risco, na Universidade Federal de Santa Catarina. Mestre em Sociologia. Especialista em Gestão das Organizações Públicas. Especialista em Direito Empresarial. Graduado em Ciências Jurídicas. Exerceu o cargo de Analista Judiciário no Tribunal de Justiça da Paraíba durante oito anos. Professor efetivo do Curso de Gestão Pública, na Unidade Acadêmica de Gestão Pública da Universidade Federal de Campina Grande. É pesquisador com ênfase em conflitos ambientais, meio ambiente, sociedade de risco, legislação ambiental, desenvolvimento sustentável, políticas públicas relacionadas ao acesso à água e saneamento. É membro atuante em diversos grupos de pesquisa. É membro da rede de pesquisa WATERLAT, http://www.waterlat.org/Members.html\#brazil. Pesquisador da Rede JUST-Side (Programa Iberoamericano de Ciencia y Tecnología). Membro da Associação Latino Americana de Sociologia - ALAS. E-mail: irivaldo.cdsa@gmail.com ou prof.irivaldo@ufcg.edu.br

${ }^{2}$ Graduado em Direito pela Universidade Estadual da Paraíba, mestre em Ciências Jurídicas pela Universidade Federal da Paraíba e doutor em Recursos Naturais pela Universidade Federal de Campina Grande. Em março de 2016 obteve com louvor o título de doutor em Direito da Cidade pela Universidade do Estado do Rio de Janeiro, tendo feito estágio de doutoramento sanduíche pela Universidade de Paris 1/Pantheón-Sorbonne (CAPES-COFECUB). É autor dos livros ?Licenciamento ambiental: aspectos teóricos e práticos?(6. ed. Fórum, 2017), "Introdução ao direito ambiental" (Del Rey, 2009) e ?Direito ambiental: tópicos especiais? (UFPB, 2007), além dos vários artigos científicos e capítulos de livros. É organizador de várias obras, a exemplo de "Direito ambiental: o meio ambiente e os desafios da contemporaneidade" (Fórum, 2010) e ?Planejamento urbano de energias renováveis: diálogos franco-brasileiros? (Editar, 2016). Em-mail: taldenfarias@gmail.com
} 


\section{INTRODUÇÃO}

Diante das crises vivenciadas atualmente no cenário nacional e internacional, o acesso à água e ao esgoto tratado são das mais graves, na medida em que falta acesso a esses dois serviços essenciais, atingido de forma desigual diferentes camadas da população, principalmente as mais vulneráveis, numa expressão clara de desigualdade social. Há uma patente irregular distribuição da água e dos serviços de esgotamento sanitário, mesmo que esses sejam essenciais à vida, sendo direitos fundamentais, não cumpridos pelo poder público. Outra questão que é preciso ser verificada é a regulação da água, ainda bastante frágil, talvez em decorrência de deficiências dos órgãos fiscalizadores e da necessidade de uma discussão mais profunda no Direito Ambiental.

O problema que ensejou o presente ensaio parte da necessidade de se tutelar a água no âmbito do seu ciclo urbano, o que preocupa bastante, na medida em que os países, incluindo-se o Brasil, são essencialmente urbanos, e há um aumento da demanda por água para consumo doméstico e industrial, sendo essencial que se cuide para que as águas dos mananciais municipais, estaduais ou federais, bem como as águas da chuva e do subsolo sejam utilizados da melhor forma possível. Portanto, tem-se aí um sistema complexo interligado que inclui cuidados com o solo, com as florestas, com a pureza do ar, entre outros fatores, que poderão se refletir na qualidade da água e, consequente acesso à ela. O objetivo do trabalho é justamente descrever o ciclo urbano da água, abordando de que forma ocorre a tutela jurídica do mesmo.

Talvez abordar exclusivamente como ocorre a tutela jurídica do ciclo urbano da água não seja suficiente para se problematizar acerca de uma injusta distribuição e, por conseguinte, injusto acesso à água, sendo fundamental refletir a partir de um marco teórico que transcenda o fenômeno jurídico como forma de buscar explicar as dinâmicas sociojurídicas que atravessam esse ciclo.

Dessa forma, a hipótese aqui estabelecida diz respeito à existência de um baixo grau de regulação do ciclo urbano da água, o que favoreceria a condução à escassez ou, até mesmo, uma distribuição injusta da água. Quanto ao esgotamento, a lógica é parecida, às vezes tem-se a água, mas não se possui o esgoto, ou tem-se a água e o esgoto, mas o mesmo não é tratado, enfim, um leque de possibilidades que apontam para uma ineficiência da ação do Estado na implementação de políticas públicas. Para se ter uma ideia, muitas cidades do nordeste semiárido, norte de Minas Gerais, até mesmo São Paulo, passam ou já passaram pelos efeitos do racionamento da água ou de interrupções no abastecimento e, certamente, os efeitos não são sentidos de modo uniforme nas cidades considerando-se estratos da sociedade, por exemplo, por bairros, por renda, ou por 
atividade econômica, enfim, os efeitos da falta de acesso ou escassez de saneamento básico são sentidos de modo diferenciado.

É preciso levar em consideração que há um processo muito forte de desconstrução de um sistema público de fornecimento de água e saneamento, inclusive como contrapartida para concessão de empréstimos nacionais e internacionais, como é o caso da Companhia de Água e Esgotos (CEDAE) do Rio de Janeiro, além do caso do lançamento de ações da SABESP (Companhia de Saneamento Básico do Estado de São Paulo) na bolsa de valores, ambas numa lógica específica de mercado. Como estratégia metodológica foi utilizada a pesquisa bibliográfica e documental aliada à análise de dados secundários sobre o saneamento básico, no caso, o abastecimento de água e o esgotamento sanitário.

\section{EXPLICITANDO O CICLO URBANO DA ÁGUA}

A água é essencial para a sobrevivência das inúmeras formas de vida na Terra. Inclusive, sabe-se que as agências espaciais quando estão em busca de vida em outros planetas começam com a procura da existência de água, pois havendo água tem-se uma das condições essenciais para que organismos possam se desenvolver. Ultimamente, tem-se pensado consideravelmente na conservação de água potável nas décadas que se seguem, inclusive na fabricação de água, principalmente, porque há um processo de mudanças climáticas consolidado que avança e que vem alterando a temperatura da Terra, tendo como efeito visível a escassez de água, a mudança nos ciclos chuvosos, o esvaziamento de reservatórios e a desertificação.

Por outro lado, tem-se um processo intenso de urbanização, transformando a paisagem de rural para urbana, com médias e grandes cidades necessitando cada vez mais de água, principalmente para o fornecimento às indústrias e à agricultura de exportação (ECHAID, 2013), bem como existindo a exigência de um crescimento econômico cada vez maior que deveria importar-se com as condições de estoque de água para fazer face aos usos múltiplos da população. Fato é que estudos apontam para a modificação do ciclo da água nos espaços urbanos, causado, especialmente, pelo crescimento dos mesmos (SWYNGEDOUW et al, 2016), apontando como causa principal a falta de planejamento das gestões públicas.

Swyngedouw et al (2016) aponta que há uma crescente utilização dos reservatórios subterrâneos de água para diversos fins, sem a preocupação da respectiva recarga, sem planejamento. Parece que esse cenário também atinge espaços urbanos, na medida em que qualquer pessoa perfura poços, sem nenhum tipo de fiscalização, a revelia de um planejamento conectado com uma possível recarga dos mananciais, sendo possível esperar um colapso desse sistema. É comum se constatar em diversas regiões brasileiras, nas cidades de pequeno e médio 
porte, cidadãos e empresas perfurando poços sem autorização legal, sem nenhum estudo prévio de impacto ambiental dessas intervenções, bem como sem uma avaliação séria por parte dos órgãos reguladores, podendo inclusive submeter as pessoas à contaminação com a ingestão da água desses poços.

Isso diz respeito ao ciclo urbano da água, ou de forma mais técnica, ao ciclo hidrológico, englobando os processos que se efetivam para a água chegar em seu destinatário final, tratando-se de uma matéria complexa em sua essência visto que é de se questionar se nas cidades ao se fazer uma obra se planeja o impacto que se causa a esse processo da natureza que, certamente, é alterado pela ação humana. É importante refletir sobre a proteção das nascentes de água que, geralmente, estão localizadas fora do ambiente urbano, e que formam reservatórios, rios, riachos, necessários ao abastecimento urbano.

Portanto, acredita-se que uma premissa deva ser estabelecida aqui, para que haja uma proteção ao ciclo urbano da água é preciso pensar além dos limites territoriais das cidades, e cuidar da proteção das nascentes para poder cuida da água que abastece os centros urbanos. Veja-se a complexidade desse processo que desafia a divisão de atribuições administrativas previstas na Constituição Federal e na legislação infraconstitucional.

Assim é pertinente refletir-se a partir da abordagem de Britto et al (2016) que defende que há uma escassez socialmente construída, na medida que existem interesses hegemônicos em relação à mercantilização da água, um certo racismo nessa distribuição no qual se prioriza mais o abastecimento e o saneamento de áreas nobres e turísticas de uma cidade. Esse enfoque problematiza sobremaneira o modo de distribuição da água e do saneamento nas zonas urbanas do país. Isso entra em rota de colisão com os fundamentos preconizados no diploma legal conhecido como Estatuto das Cidades (Lei n. 10.257/2001) que estabelece a necessidade premente de se ter uma política urbana pautada na função social das cidades, incluindo nessa categoria o saneamento, que envolve o abastecimento de água e o esgoto tratado, além da preservação do ambiente natural e dos recursos naturais.

Portanto, há um conjunto de diretrizes que atuam na proteção da água e do seu entorno, pois é preciso compreender que a água compõe um sistema, cuja complexidade é a tônica, sendo necessário que se analise de forma transdisciplinar o fenômeno, de modo a pensar na vegetação, solo, e outros de forma integrada. Desse modo, preservar esse todo e as partes é cuidar do meio ambiente e beneficiar a preservação do ciclo urbano da água nas cidades. Segundo Swyngedouw et al (2004), a circulação da água faz parte do processo de circulação de dinheiro e capital, e outros serviços de bens urbanos, compondo a economia política que estrutura relações de poder, 
interferindo diretamente numa suposta forma e coerência do espaço urbano. Partindo dessa ideia, mecanismos de exclusão do acesso à água, ao saneamento básico, poderia ter explicação através da exclusão hidrossocial, ou pelo menos ser uma chave de análise social, sócio-técnica, jurídica, e a partir daí novos mecanismos de decisão, de regulação e de participação poderiam ser pensados. A abordagem hidrossocial vê a circulação da água como um processo físico e social combinado, como um fluxo hibridizado, em que a natureza e a sociedade se fundem de maneira inseparável (SWYNGEDOUW, 2004).

De acordo com essa abordagem, o acesso ou a falta (ou exclusão) em relação à água, inclusive ao esgotamento sanitário, são construídos historicamente dentro de um ciclo hidrossocial, portanto, não estão dados, ou seja, populações ou comunidades pobres com menor capacidade de entendimento e de defesa de seus direitos são mais facilmente atingidos por essa escassez hidrossocial (BRITTO et al, 2016). Dessa forma, não haveria um mero ciclo urbano da água, mas um ciclo hidrossocial da água. Porém é importante destacar que há um conceito mais utilizado para ciclo da água na gestão dos recursos hídricos que diz respeito ao movimento e troca da água na Terra (PENA-GUZMAN et al, 2016) em processos complexos que acabam por integrar elementos hidrológicos, hídricos, abastecimento, distribuição, uso do recurso, tratamento e reutilização.

Então é perceptível que no contexto urbano é muito complexa a análise e, certamente, a regulação. Segundo Peña-Guzmán et al (2016), o ciclo urbano da água conta atualmente com “inclusión del servicio de prestación de agua y los usos que se le da en áreas urbanas, como suministro de agua potable, drenaje de agua de lluvia y residuales, y manejo y tratamiento de las aguas". Portanto, são diversas as variáveis, inclusive a demanda por um aparato técnico forte, erigindo daí a preocupação dessa constatação que é justamente até que ponto o ordenamento jurídico, conjugado com o aparato estatal, está preparado para tal desiderato.

É preocupante pensar, e muitos usuários não refletem sobre isso, como a água chega nas residências, indústrias e outras dependências, a questão que incomoda é certamente a isonomia no acesso a esse serviço, quantidade e qualidade, tema que pode ser objeto de estudos que envolvam a ecologia política. Desse modo, compartilha-se da abordagem de Swyngedouw et al (2016), no que se refere à necessidade de se fazer uma leitura a partir da ecologia política sobre as mudanças urbanas, daí entra a questão do ciclo da água, uma vez que ao longo dos anos o meio ambiente foi modificado com o crescimento e as transformações provocadas pelo meio urbano, que se metamorfosea cada vez mais, porém, implicando num aumento de demanda, inclusive de água (PUJOL et al, 2014). No quadro 1 colocam-se algumas observações feitas por Swyngedouw et al 
(2016) que merecem ser levadas em conta nesse processo do olhar da ecologia política e da hidrossocialidade face o ciclo urbano da água:

\section{Quadro 1 - argumentos que devem ser levados em consideração na análise jurídico-ambiental do} ciclo urbano da água

os processos de mudança socioambiental transformam tanto os ambientes sociais como os físicos e produzem ambientes sociais e físicos com qualidades novas e distintas. Os meio ambientes são construções a partir de combinações sócio-físicas que são produzidas ativa e historicamente, tanto em termos de seu conteúdo social, como de suas qualidades físico-ambientais;

os meio ambientes produzidos são resultado historicamente específicos de processos socioambientais;

É importante ter em mente como estão as relações sociais de poder nas mais diversas esferas da sociedade, pois isso será definidor nas transformações socioambientais. São essas geometrias de poder e os atores sociais que as realizam, que finalmente decidem quem terá acesso ou controle, e quem será excluído desse acesso e controle, sobre recursos e outros componentes do meio ambiente;

Para a ecologia política é importante saber quem ganha e quem perde, o que é extramente útil para os atores políticos em posição de decisão e legisladores no momento de transformar em lei determinada política e propor mecanismos de regulação com a intenção de dar acesso igualitário;
A transformação ambiental não é independente das lutas de classe, gênero, étnica e outras; as perspectivas ecológico-políticas também buscam questionar os processos concretos de reconstrução e reformulação ambiental e argumentam que a sustentabilidade é alcançada através de um processo de re-construção sócio-ambiental controlada e organizada democraticamente. O programa político de Ecologia Política, portanto, é aumentar o conteúdo democrático dos processos de construção socioambiental, identificando as estratégias através das quais uma distribuição mais equitativa do poder social poderia ser alcançada e uma maior incluindo a produção ambiental.

As perspectivas ecológico-políticas também buscam questionar os processos concretos de reconstrução e reformulação ambiental e argumentam que a sustentabilidade é alcançada através de um processo de re-construção socioambiental controlada e organizada democraticamente. O programa político de Ecologia Política, portanto, é aumentar o conteúdo democrático dos processos de construção socioambiental, identificando as estratégias através das quais uma distribuição mais equitativa do poder social poderia ser alcançada e uma maior incluindo a produção ambiental;

Todos os processos sócio-espaciais também são, invariavelmente, baseados na transformação ou metabolismo de componentes físicos, químicos e biológicos; 
As perspectivas ecológico-políticas procuram decifrar a natureza das relações sociais que se desenvolvem entre indivíduos e grupos sociais e como estes, por sua vez, são mediados e estruturados por processos de mudança ecológica; em alguns lugares e para algumas pessoas, muitas vezes essas melhorias levam à deterioração das qualidades e condições sociais e físicas de outros lugares;

Os processos de mudança socioambiental, portanto, nunca são socialmente ou ecologicamente neutros. Isso causa condições em que determinadas trajetórias particulares do processo de mudança socioambiental minam a estabilidade e a coerência de alguns grupos e lugares sociais, enquanto podem melhorar a sustentabilidade de outros grupos e lugares. Em resumo, o estudo ecológico-político do processo de urbanização revela a natureza intrinsecamente contraditória do processo de mudança socioambiental e evidencia os inevitáveis conflitos (ou deslocamentos no tempo e no espaço) gerados pela mudança socioambiental.

Comunga-se da preocupação do autor em relação às necessidades crescentes da população no meio urbano o que, inevitavelmente, exigirá um processo de transformação socioambiental cada vez mais forte, para poder suportar a pressão das mudanças urbanas contemporâneas Swyngedouw et al (2016). É importante destacar que o processo de urbanização contínuo na história provocou mudanças em relação ao ciclo da água, considerando que a compreensão de que o ciclo urbano da água nada mais é do que a circulação da água em território classificado como urbano.

Os estudos de Swyngedouw et al (2016) vem problematizar essencialmente a transformação do ciclo urbano da água, que tem sido modificado ao longo da história para satisfazer as necessidades da crescente população e produção, agrícola e industrial, o mesmo traz uma questão que é a modificação dos lençóis freáticos, que estão secando e sendo contaminados o que pode inviabilizar o fornecimento de água potável nessas regiões, e isso está acontecendo em Telaviv, Londres, Atenas. Nesse processo, poderia ser incluída por exemplo a obra da transposição do São Francisco, e outras, feitas para o abastecimento urbano, principalmente para que não houvesse um colapso na produção das médias e grandes cidades, pelo menos é isso que se construiu com a ativação do Eixo Leste da obra. Tucci (2008, p. 99) já enfatizava que essas águas urbanas se constituíam num grande problema em virtude do seguinte:

1) Falta de tratamento de esgoto: grande parte das cidades da região não possui tratamento de esgoto, lançando os efluentes na rede de esgotamento pluvial, que escoa pelos rios urbanos (maioria das cidades brasileiras); 
2) outras cidades optaram por implantar as redes de esgotamento sanitário (muitas vezes sem tratamento), mas não implementam a rede de drenagem urbana, sofrendo freqüentes inundações com o aumento da impermeabilização;

3) ocupação do leito de inundação ribeirinha, sofrendo freqüentes inundações;

4) Impermeabilização e canalização dos rios urbanos com aumento da vazão de cheia (sete vezes) e sua freqüência; aumento da carga de resíduos sólidos e da qualidade da água pluvial sobre os rios próximos das áreas urbanas;

5) deterioração da qualidade da água por falta de tratamento dos efluentes tem criado potenciais riscos ao abastecimento da população em vários cenários, e o mais crítico tem sido a ocupação das áreas de contribuição de reservatórios de abastecimento urbano que, eutrofizados, podem produzir riscos à saúde da população.

Esse é um quadro ruim para quem? Quem efetivamente sofre com um sistema de saneamento básico injusto? Essa é uma questão a ser respondida, mas com base nos estudos realizados no campo sócio-jurídico é preciso avançar no sentido de compreender o ciclo urbano da água como sendo um ciclo hidrossocial, no qual o poder e outros fatos moldam seus caminhos pela urbe. Na figura 1 fica exposta a complexidade do ciclo urbano da água, sendo necessário órgãos técnicos administrativos, reguladores e judiciais capacitados para analisar e tutelar o direito fundamental ao saneamento.

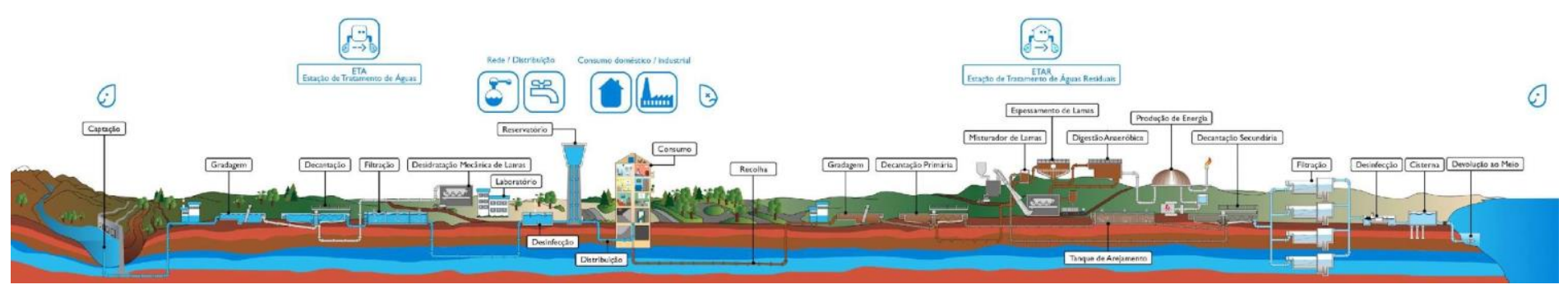

Figura 1 - Demonstração do processo de captação de água até o seu devido tratamento após consumo

Fonte: ADRA, Portugal, http://www.adra.pt/content/index.php?action=detailfo\&rec=1976\&t=Ciclo-urbano-da-agua 3 COMO ESTÁ POSTO JURIDICAMENTE NO BRASIL E A TUTELA EM SI 
A legislação brasileira posiciona o abastecimento de água ${ }^{3}$ potável dentro do conceito de saneamento básico e público, conforme a Lei Federal n. 11.445/2007, Lei de Diretrizes Nacionais para o Saneamento Básico (LDNSB), que estrutura a Política Nacional de Saneamento Básico (PNSB), e seu decreto de regulamentação (Decreto n. 7.217/2010) no art. 2, estão postos como princípios fundamentais: (i) abastecimento de água potável; (ii) coleta e tratamento do esgotamento sanitário; (iii) drenagem e manejo das águas pluviais urbanas; e (iv) limpeza e manejo de resíduos sólidos urbanos (coleta e disposição final do lixo). Portanto, de acordo com o art. 3 da mesma lei, saneamento básico é abastecimento de água potável, esgotamento sanitário tratado, limpeza urbana e manejo de resíduos sólidos, drenagem e manejo de águas pluviais. Apesar de não se ter esse categoria "ciclo urbano da água" na legislação brasileira, o que chega mais próximo é a Resolução do Conama n. 303/2002, que define a categoria jurídica "área urbana consolidada"4, como sendo,

XIII - área urbana consolidada: aquela que atende aos seguintes critérios:

a) definição legal pelo poder público;

b) existência de, no mínimo, quatro dos seguintes equipamentos de infraestrutura

urbana:

1. malha viária com canalização de águas pluviais,

2. rede de abastecimento de água;

3. rede de esgoto;

4. distribuição de energia elétrica e iluminação pública;

5. recolhimento de resíduos sólidos urbanos;

6. tratamento de resíduos sólidos urbanos; e

c) densidade demográfica superior a cinco mil habitantes por $\mathrm{km} 2$.

Desse modo, tem-se um elemento para instruir a tutela jurídica do ciclo urbano da água, compreendendo, inicialmente, o que significa para o ordenamento jurídico a área urbana, em que a mesma é objeto de uma Política Urbana que prevê requisitos específicos mínimos para se conceder qualidade de vida para quem reside nas cidades. É importante destacar que estão incluídos como itens essenciais para essas áreas urbanas o abastecimento de água potável e o esgotamento sanitária, que deixou de ser a instalação de uma mera rede, para ser um sistemas mais complexo, como dispõe a legislação "constituído pelas atividades, infra-estruturas e instalações operacionais de coleta, transporte, tratamento e disposição final adequados dos esgotos sanitários, desde as ligações prediais até o seu lançamento final no meio ambiente" (Lei n. 11.445/2007, art. 3,

\footnotetext{
${ }^{3}$ é importante deixar claro que "abastecimento de água" é diferente de "recursos hídricos", que dizem respeito aos corpos d'água que fornecem água para o abastecimento e são regulados pela Política Nacional de Recursos Hídricos, com lei própria, Lei n. 9.433/97.

${ }^{4}$ A Lei n . 13.645/2017 detalha mais o que seria essa "área urbana consolidada".
} 
I, b). Dessa forma, o esgotamento sanitário estabelece uma série de etapas que compõe a PNSB, não sendo o simples ato de receber as águas utilizadas e lançá-las em tubulações e depois no meio ambiente, implica em tratamento adequado pelo Poder Público, e em adequações dos usuários do sistema. É uma atividade complexa que necessita de uma forte regulação.

Quanto à PNSB, ela está umbilicalmente ligada à Política Nacional de Recursos Hídricos (PNRH) de 1997, a lei n. 9.433, uma vez que os três artigos iniciais desse último diploma legal estabelecem princípios fundamentais dessa política que não podem ser desconsiderados, uma vez que tanto o acesso à água e esgoto tratado são considerado direitos humanos, portanto, fundamentais para a dignidade humana, cabendo às gestões públicas sua concretização. Para que isso ocorra, defende-se aqui a necessidade de se tutelar o ciclo urbano da água como algo único e interligado, desde o manancial até o descarte ou reaproveitamento das águas utilizadas.

Essa é uma questão que não é negociável, sem água e esgotamento tratado não há como se falar em qualidade de vida, num "bem viver", que já foi perdido, ou nunca constituído em alguns territórios no mundo, ou que está sendo dissolvido com a falta de acesso à água e serviços sanitários. É importante destacar que no contexto de uma política urbana mais ampla o direto à cidade é um fundamento erigido pela Lei n. 10.257/2001, que só se consubstanciará como tal se houver acesso à água tratada e a todo o equipamento sanitário que, inclusive, possa oferecer o tratamento e, daí, essa água possa ser reutilizada.

Numa sociedade complexa (LEITE, 2015) e extremamente urbanizada, não seria admissível pensar em bem-estar nas cidades sem o acesso à água, a uma rede de esgoto tratado e reuso dessas águas. Frise-se ainda que a Carta Magna de 1988, no art. 225, parágrafo primeiro, menciona que para se concretizar o direito fundamental ao meio ambiente ecologicamente equilibrado é necessário: "preservar e restaurar os processos ecológicos essenciais e prover o manejo ecológico das espécies e ecossistemas" [GRIFO NOSSO]; portanto preocupar-se com a preservação das nascentes é imperativo para que todo o processo de "produção" da água, naturalmente, seja preservado e haja um impacto positivo nas cidades, bem como em relação à disposição final dessas águas utilizadas.

Nesse planejamento deve entrar a observância da legislação quanto às Áreas de Preservação Permanente (APPs) ${ }^{5}$, seja urbana ou não, no sentido de preservar, repisando, as nascentes, os reservatórios de água, sendo importante asseverar que é preciso manter a floresta "em pé" para que haja água. Dessa forma, ao criar as APPs o legislador quis resguardar diretamente

\footnotetext{
${ }^{5}$ Lei $12.651 / 2012$, Art. 4 은
} 
a flora, a fauna, os recursos hídricos e os valores estéticos, de maneira a garantir o equilíbrio do meio ambiente e a consequente manutenção da vida humana e da qualidade de vida do homem em sociedade, deixando determinadas áreas a salvo do desenvolvimento econômico e da degradação, posto que as florestas e demais formas de vegetação guardam íntima relação com os elementos naturais citados (FARIAS; CORREIA, 2016). Destaque-se que o Superior Tribunal de Justiça já consagrou a importância ecológica das $\mathrm{APPs}^{6}$. Outro instrumento relevante para esse planejamento integrado do ciclo urbano da água é o plano diretor, sendo imprescindível que haja a previsão acerca da água, do solo e da vegetação, de modo a adotar um modelo de desenvolvimento sustentável que proporcione a preservação dos cursos de água e a garantia que haverá a constituição de uma política de saneamento local ou regional, numa compreensão de política urbana alargada que tenha um eixo ambiental forte (NAZARETH, 2018).

A partir dessas considerações, um ponto importante a se questionar é: de quem seria a responsabilidade de gerir todo esse sistema? A legislação pátria trouxe uma responsabilidade nova aos municípios (QUINTSLR et al, 2014) que é justamente cuidar do saneamento básico, o que, no caso brasileiro, é preocupante pelos problemas financeiros corriqueiros para a realização das ações necessárias para que o mesmo ocorra, o que não isenta a União, os estados e o distrito federal de suas responsabilidades. Dentre essas responsabilidades municipais destaque-se: (i) elaborar e aprovar a Política Municipal de Saneamento Básico, através da qual será definido o modelo jurídicoinstitucional, as funções de gestão dos serviços públicos de saneamento e estabelecida a garantia do atendimento essencial à saúde pública, aos direitos e deveres dos usuários, e ainda a instância de controle social da gestão dos serviços; (ii) elaborar e aprovar o Plano Municipal de Saneamento Básico, cujo conteúdo é definido na Lei; (iii) constituir a entidade reguladora e fiscalizadora dos serviços públicos de saneamento básico ou definir a qual entidade existente será delegada essa função; (iv) definir a entidade responsável pelo controle social dos serviços, que pode ocorrer através da criação de um conselho específico (Conselho Municipal de Saneamento Básico) ou de conselho existente, como o conselho municipal da cidade ou de meio ambiente.

O Gráfico 1 traz os dados do SNIS (2017) para se compreender o tamanho do problema no Brasil:

\footnotetext{
${ }^{6}$ REsp 1245149/MS, Rel. Ministro HERMAN BENJAMIN, 2a TURMA, julgado em 09/10/2012, DJe 13/06/2013.
} 


\section{Gráfico 1 - Situação geral do Saneamento Básico no Brasil}

Fonte: SNIS, 2017.

PB CE BA PI MA SE AL PE RN SP ES RJ MG PR SC RS MT MS GO DF AM RO AC TO PA AP RR

O diagnóstico apresentado no Gráfico 1 evidencia o fracasso da PNSB, quando se compara

a evolução da rede de água, ou seja, do fornecimento, em relação à coleta e ao tratamento, verificase uma disparidade muito grande, que aumenta conforme a região. Apenas São Paulo e Distrito Federal tem níveis de coleta e tratamento compatíveis com a expansão da rede de água. Chama atenção os estados do Norte e Nordeste que continuam sendo aqueles que mais sofrem com o baixo nível do serviço de saneamento básico, a despeito de investimentos realizados nos anos anteriores. Porém, esses dados não são precisos no que se refere à qualidade de água recebida pelos usuários.

Entretanto, é importante mencionar que os estados da região Sul padecem de níveis de coleta, tratamento e perdas ainda preocupantes. Essa situação foge dos parâmetros estipulados tanto na lei da PNRH como na lei da PNSB, afrontado diretamente seus princípios basilares. Isso levanta questionamentos acerca da regulação dos serviços relacionados diretamente ao saneamento básico, cujas responsabilidades não se encontram claras. A despeito da baixa extensão dos serviços no Paraná e Rio Grande do Sul, essa diferenciação tem endereço certo no Norte e Nordeste, o que fere fundamentos da República, previstos no art. 3 da constituição Federal de 1988, que estabelece a obrigação de erradicar a pobreza e a marginalização e reduzir as desigualdades sociais e regionais, o que parece que não foi atingido em pleno século 21,30 anos depois de promulgada a Carta Magna. Entretanto, o Tribunal de Contas da União tem constatado irregularidades em convênios que tratam do repasse de recursos para se fazer o Plano Municipal de Saneamento Básico (PLAMSAB), como, à guisa de exemplo, constatou-se que no acórdão n. 002.953/2017-0 houve o bloqueio do repasse de recursos da Fundação Nacional de Saúde (FUNASA) para 100 municípios do Piauí que estavam na iminência de fazer seu PLAMSAB, e como se verificou 
nos dados do Gráfico 1, o Piauí é um dos piores estados em termos de saneamento básico. Os diplomas legais aqui citados deixam claro a responsabilidade do gestor público em relação a essas ações essenciais, desde a captação da água até o tratamento das águas residuárias, ou seja, as águas descartadas depois do uso, e nessa seara o Brasil avançou muito pouco. Essa responsabilização do gestor pode redundar em crime de improbidade, em processo administrativo e, até mesmo, em crime ambiental.

Para além do jurídico, para se avaliar a tutela jurídica do ciclo urbano da água é necessário verificar o que a PNSB menciona em relação aos entes federados. Já se asseverou o plus que legislação trouxe responsabilizando os municípios em relação ao saneamento local, entretanto a União também possui sua responsabilidade, não só orçamentária, mas em relação à construção e institucionalização do PLANSAB (Plano Nacional de Saneamento Básico), cuja responsabilidade ficou sob a regência do Ministério das Cidades, e que fora finalizado em $2013^{7}$. Além disso, é imperiosa a ação do Ministério Público na fiscalização, acompanhamento e monitoramento, dessas obras de saneamento, especialmente relacionadas ao ciclo urbano da água, vide Quadro 2, pois a partir dessa atuação pode-se ter a formulação de inquéritos civis, denúncias quando houver a prática de crime e a provocação de órgãos administrativos chamando-os à responsabilidade.

É importante destacar que no plano internacional, dois marcos referenciais, aprovados no âmbito da Organização das Nações Unidas e estreitamente relacionados ao Plansab, merecem registro: (i) os Objetivos de Desenvolvimento do Milênio, firmado pelo Brasil e outros 190 países, em setembro de 2000, prevendo, entre outras metas, a redução em 50\%, até 2015, da parcela da população que não tinha acesso à água potável e ao esgotamento sanitário no ano de 1990 (como visto no Gráfico 1 não foi atingido, e certamente não será atingido mesmo com o adiamento para 2030); (ii) a Resolução A/RES/64/292, da Assembleia Geral das Nações Unidas, de 28 de julho de 2010, apoiada por 122 nações, com 41 abstenções e nenhum voto contrário, com forte suporte da diplomacia brasileira, e que trata dos direitos à água e ao esgotamento sanitário, afirma ser o acesso à água limpa e segura e ao esgotamento sanitário adequado um direito humano, essencial para o pleno gozo da vida e de outros direitos humanos.

7

http://www.mma.gov.br/port/conama/processos/AECBF8E2/Plansab_Versao_Conselhos_Nacionais_020520 131.pdf 
A despeito da atuação do Ministério Público foram selecionados aleatoriamente alguns estados da federação, sendo feitas consultas processuais acerca de informações sobre a atuação ministerial na proteção jurídica do ciclo urbano da água. Verifica-se que essa atuação tem crescido, entretanto, há dificuldade, e mesmo ausência de informações sobre a atuação administrativa e judicial. Chama atenção o endereço eletrônico do Ministério Público do Estado do Amazonas que se apresentou como sendo o site que menos informações possuía dentro dos que foram verificados.

\section{Quadro 2 - Breve panorama da atuação do Ministério Público nos Estados.}

MINISTÉRIO PÚBLICO FEDERAL DA PARAÍBA

MINISTÉRIO PÚBLICO DE SÃO PAULO

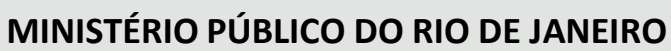

Tem atuado fortemente no monitoramento e na propositura de ações referentes às obras da transposição do São Francisco, incluindo aí o saneamento básico nas cidades a serem atendidas pela água, bem como em relação ao racionamento na cidade de Campina Grande.

Esse instituiu como coordenação de Urbanismo e Meio Ambiente que cuida das diversas bacias hidrográficas do estado, o que significa ser uma tutela até preventiva em relação ao ciclo urbano da água. Atua nas matérias relacionadas à água, saneamento, fauna, flora, resíduos, entre outros setores relevantes. Destaque-se ação civil pública ambiental impetrada por esse obrigando a empresa de saneamento de São Paulo a não lançar esgoto sem tratamento em mananciais, ou seja, a necessidade de cumprir o que preceitua a LDNSB

Possui um Núcleo de Apoio ao Meio Ambiente, que possui um Grupo de Apoio Especial ao Meio Ambiente, e em 2017 ajuizou ação para proteger e descontingenciar o Fundo de Apoio aos Recursos Hídricos, que visa justamente implementar ações nessa área, e que o governo fluminense desejava usar esses recursos em outras áreas. Em 17/10/2017, houve a homologação de Termo de Ajustamento de Conduta (TAC) assinado com governo do Estado para garantir, dentre outras medidas, o descontingenciamento do Fundo Estadual de Recursos Hídricos (FUNDRHI). Pelo acordo homologado pela 16a Vara de Fazenda Pública da Capital, o governo estadual assume o compromisso de não reter as receitas do fundo e de observar a legislação que o rege. Por lei, a arrecadação do FUNDRHI compete ao Instituto Estadual do Ambiente (INEA), a quem caberá a gestão para uso exclusivo na proteção dos recursos hídricos do Estado, em consonância com os Planos de Bacia desenvolvidos pelos Comitês de Bacia Hidrográfica e suas respectivas agências delegatárias. 


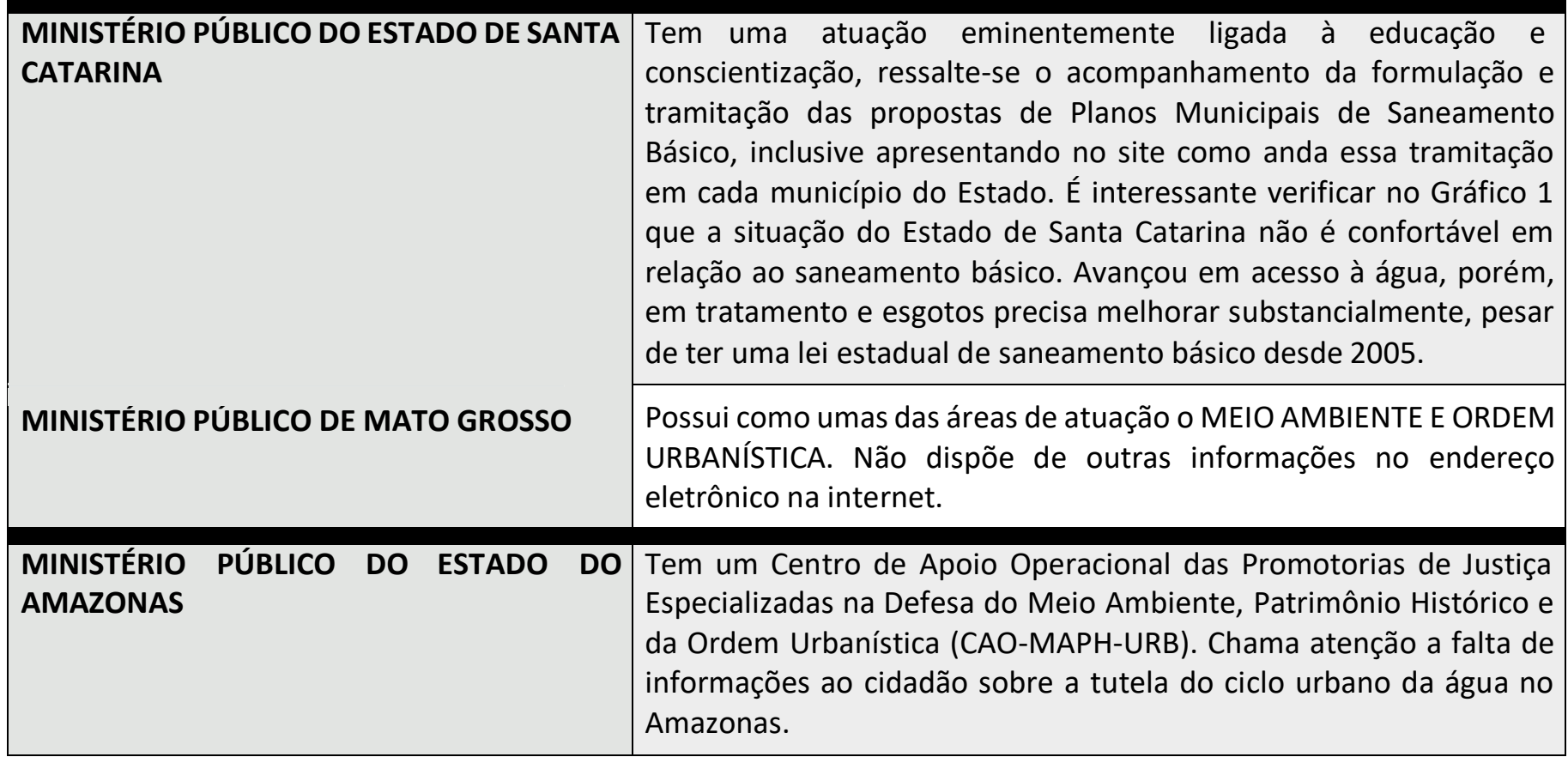

Fonte: os endereços eletrônicos de cada ministério público mencionado no quadro.

A tutela jurídica do ciclo urbano da água, no caso brasileiro, rege-se pelos diplomas legais apresentados e também pelos documentos legais dos órgãos administrativos envolvidos como o Ministério das Cidades, a FUNASA, a Agência Nacional de Águas (ANA) e, especialmente, os Planos Municipais de Saneamento Básicos, além dos planos diretores, esses últimos essenciais para o balizamento da análise jurídico-administrativa das ações referentes à proteção do ciclo urbano da água. Fez-se a coleta dos planos diretores das principais cidades brasileira em termos populacionais, de forma aleatória e confeccionou-se o quadro abaixo que ilustra bem o que se está discutindo aqui.

Quadro 3 - Amostra da abordagem do ciclo urbano da água em Plano Diretores em grandes aglomerados urbanos brasileiros.

MANAUS

O texto da Lei Complementar n. 2 de 2014 busca responsabilizar o município na proteção dos corpos d'água no território municipal, bem como todo o seu trajeto, seja para o consumo, seja para outra finalidade. Entretanto, percebe-se que por ser uma capital rodeada por importantes mananciais não deixa clara qual vai ser a política urbana em face da água, principalmente deixando muito no campo 


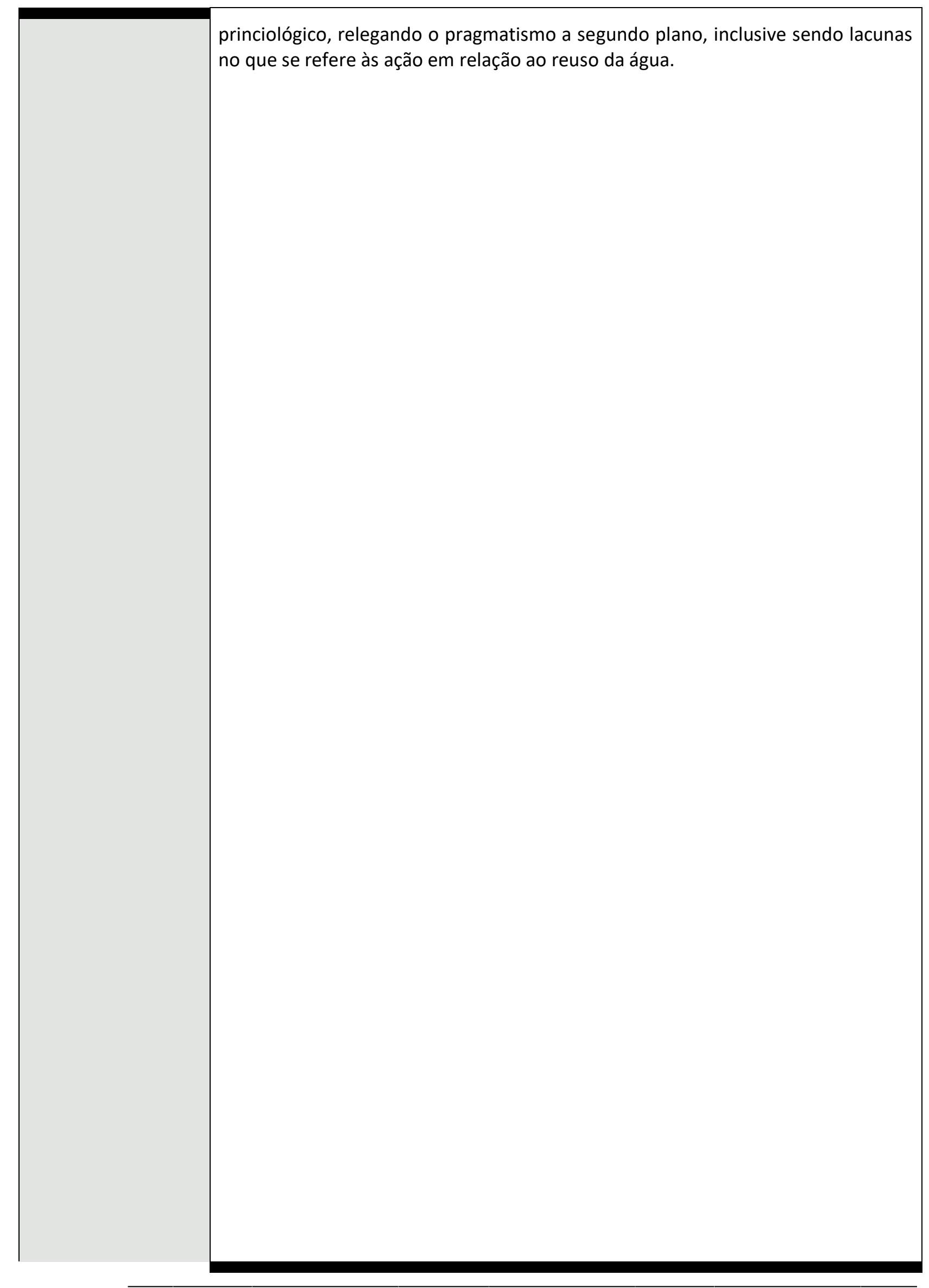




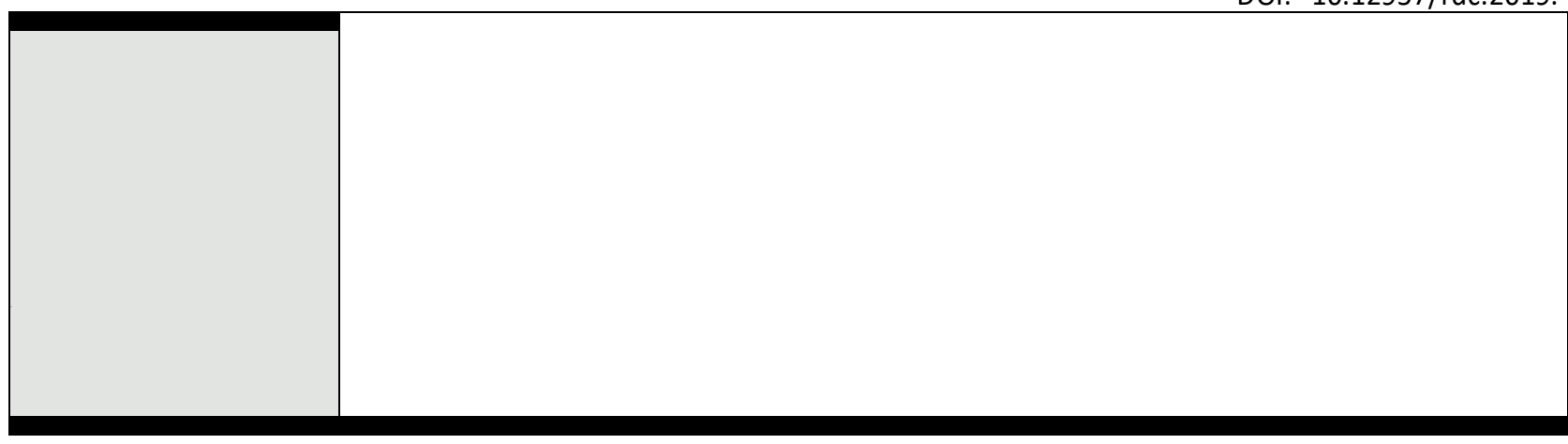




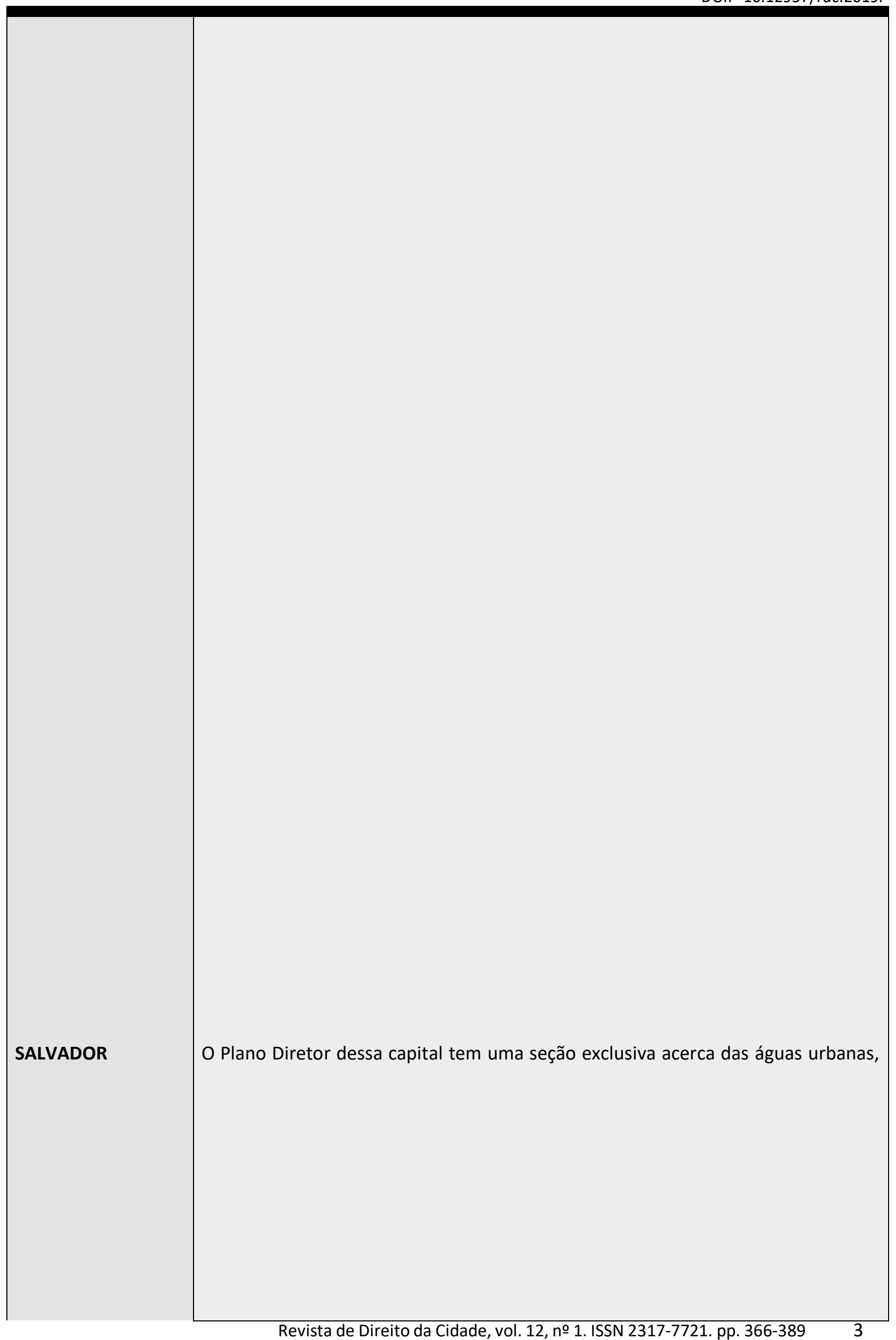




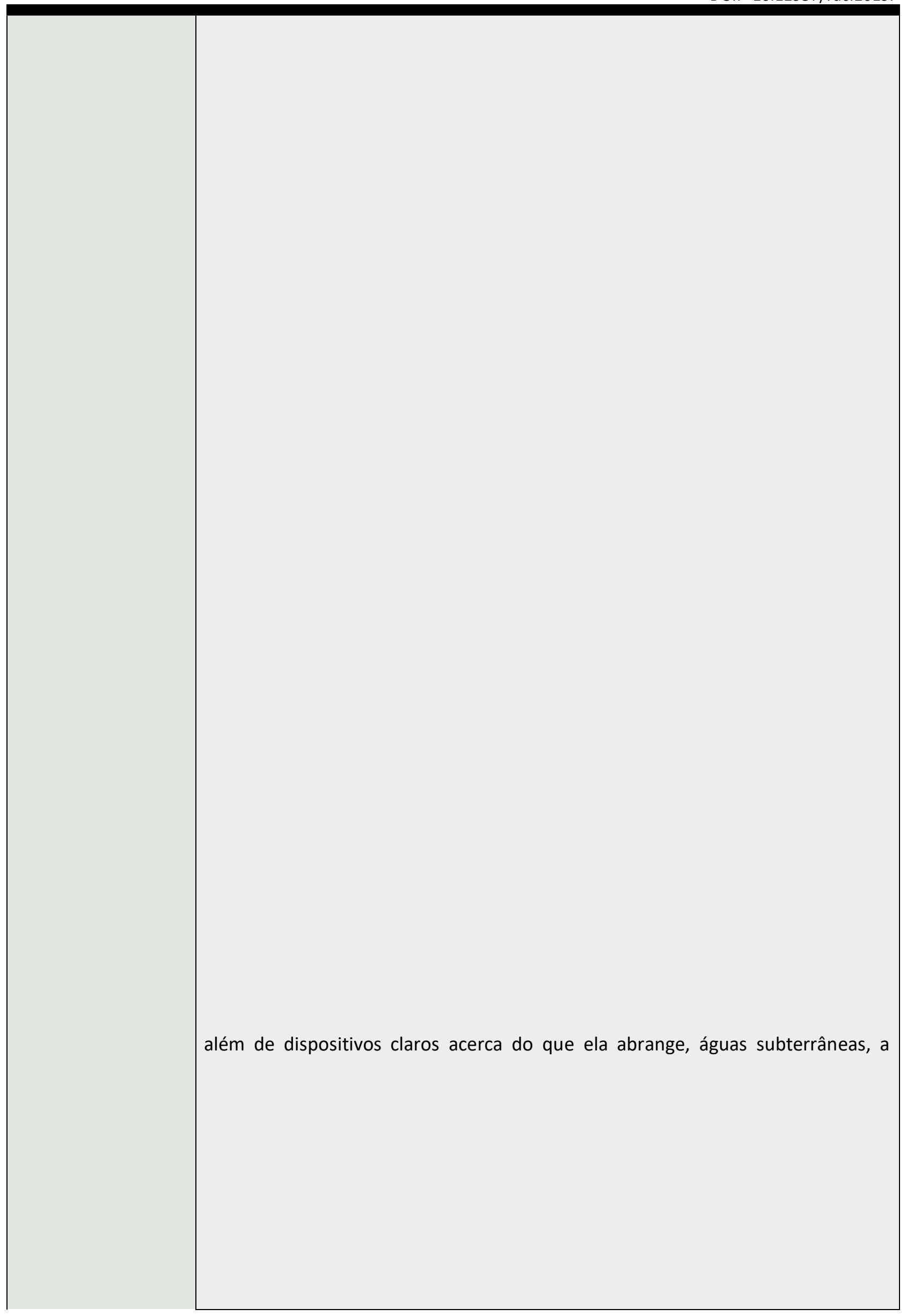




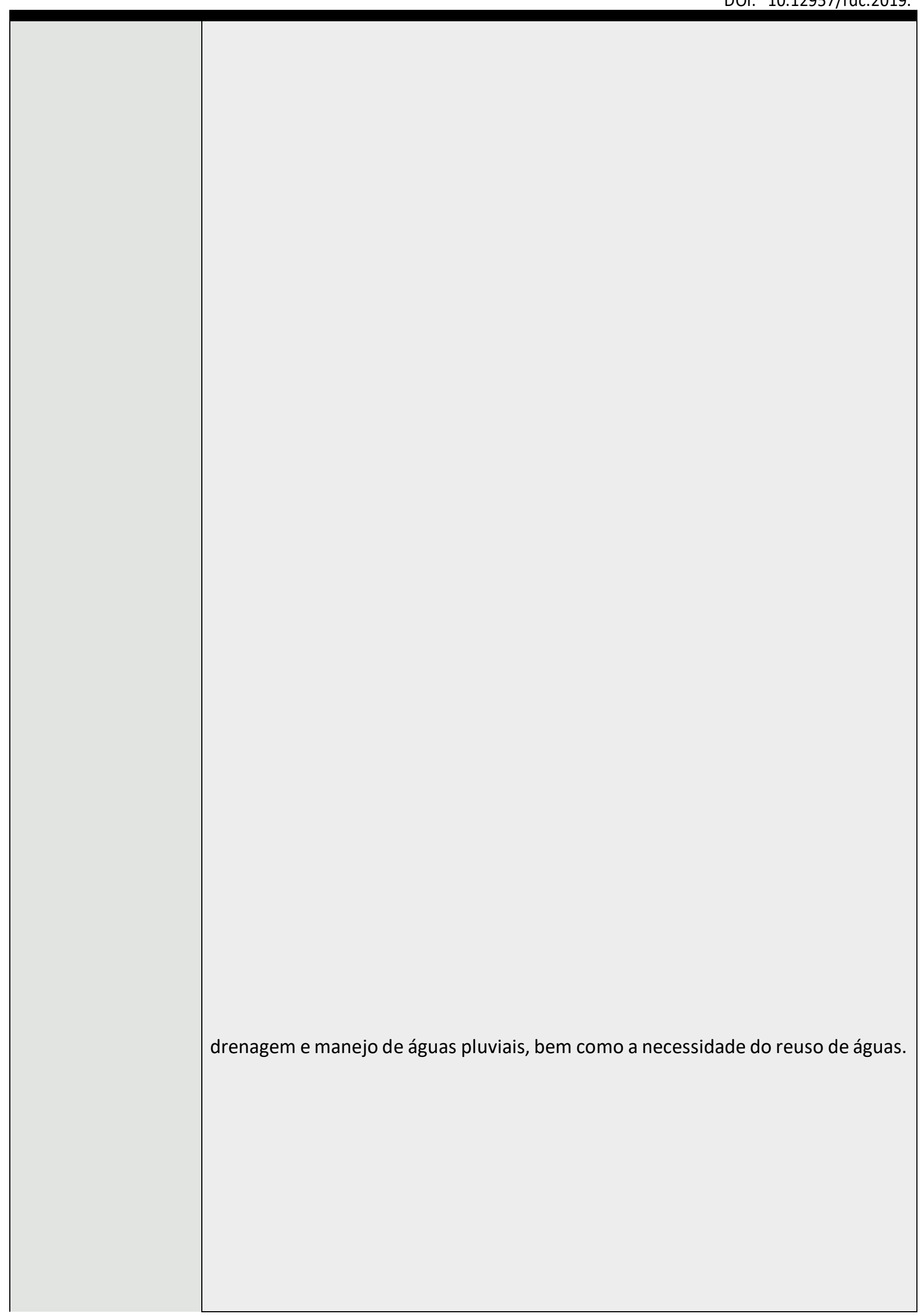




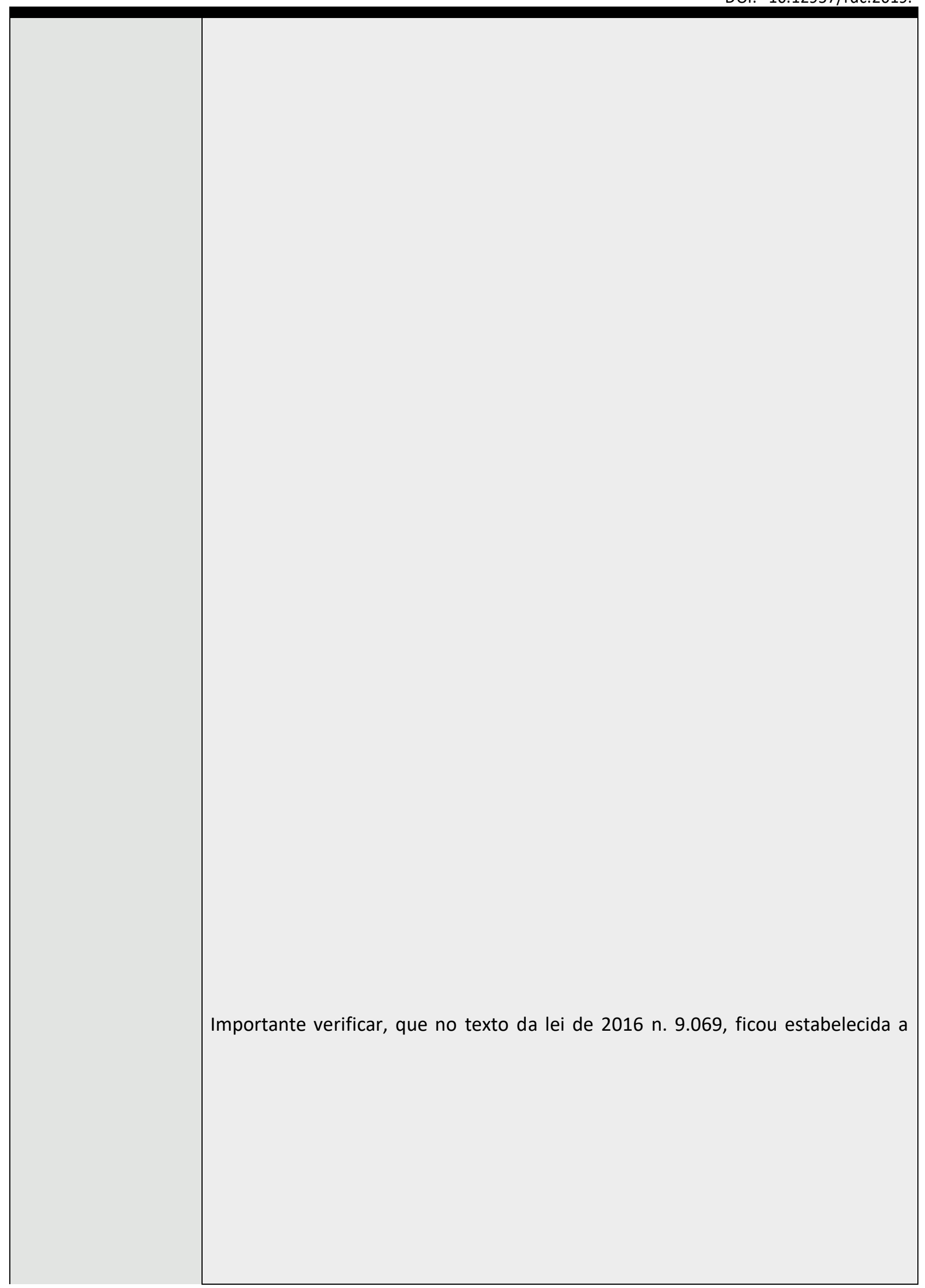




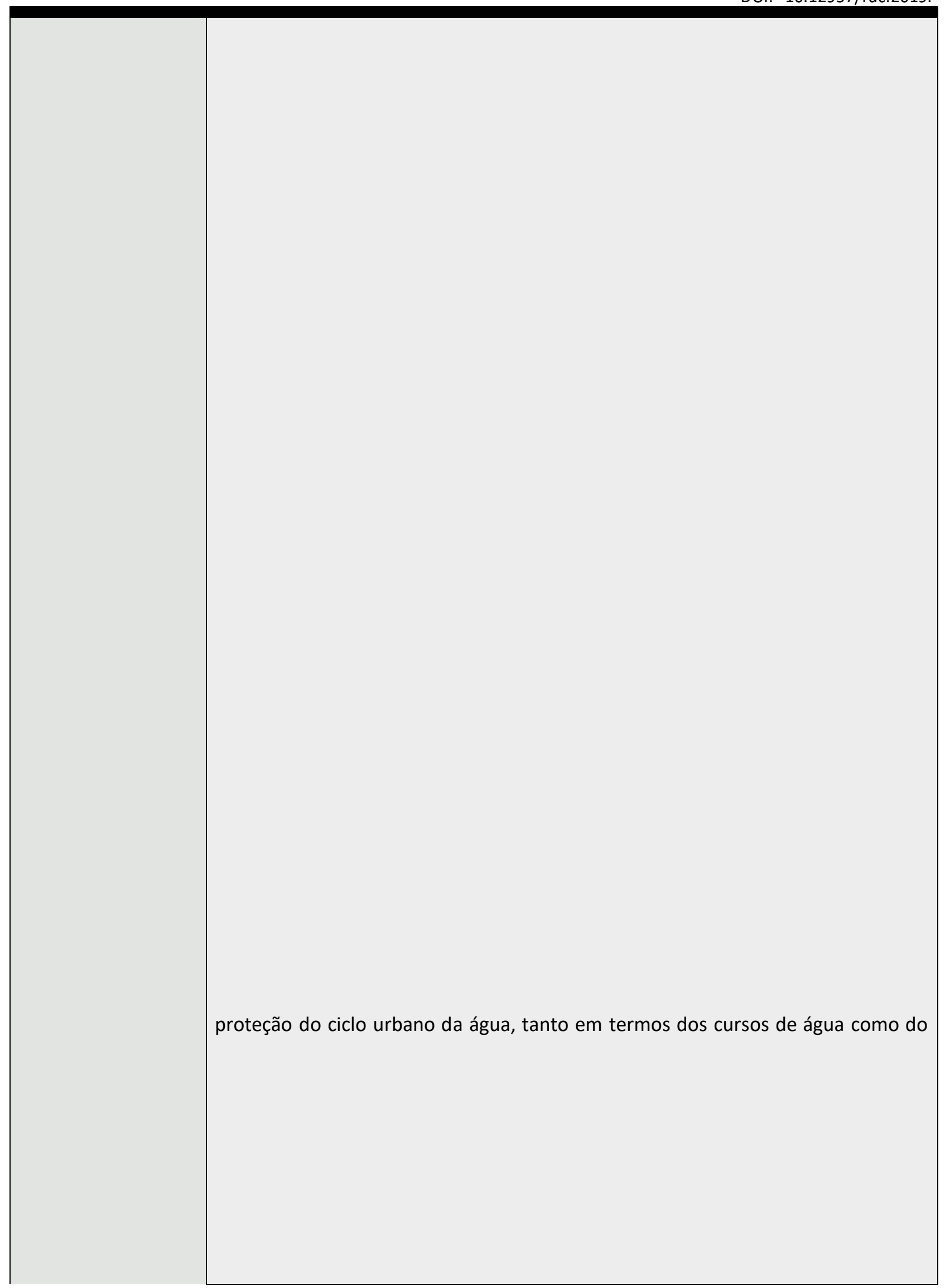




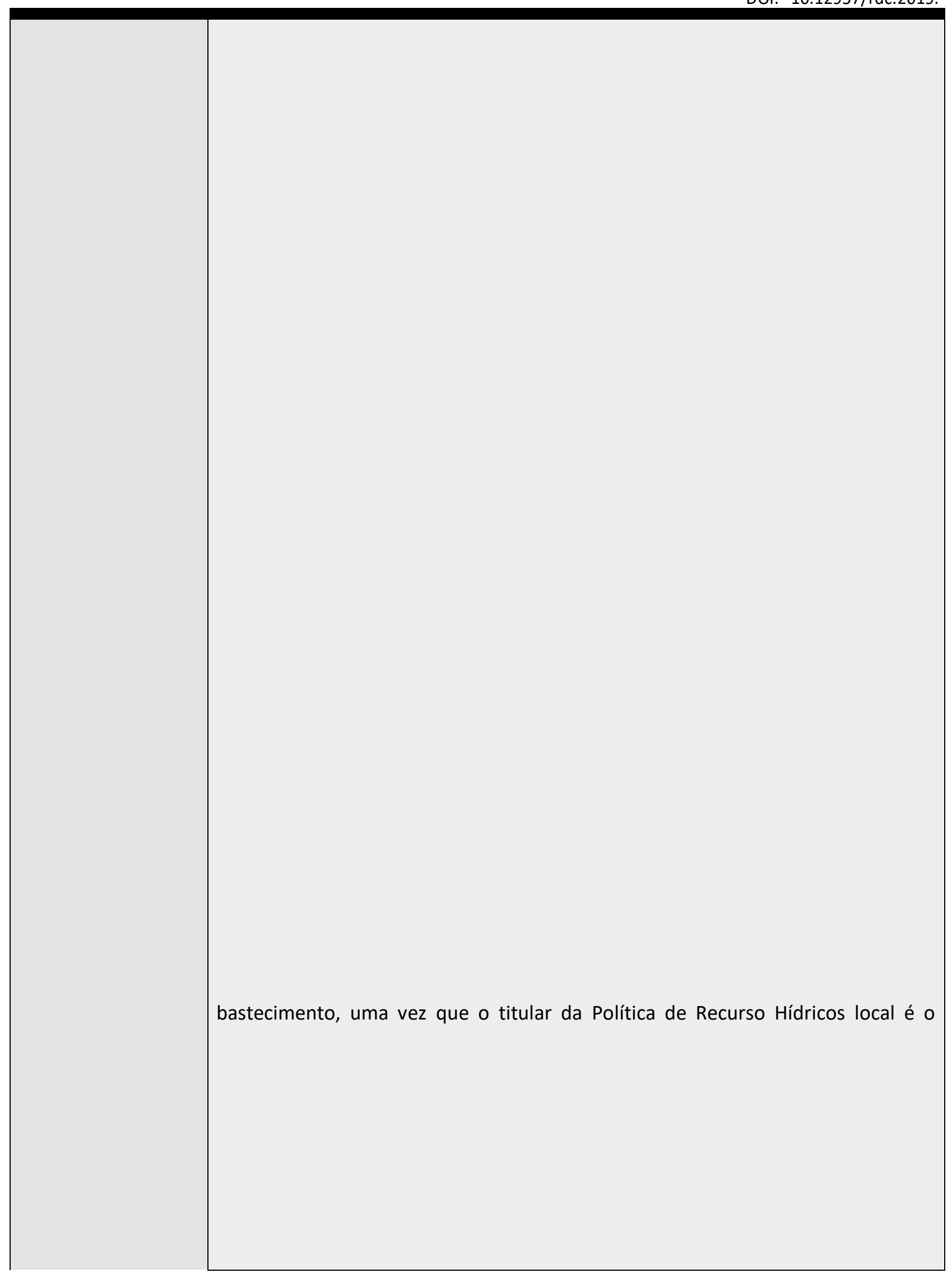




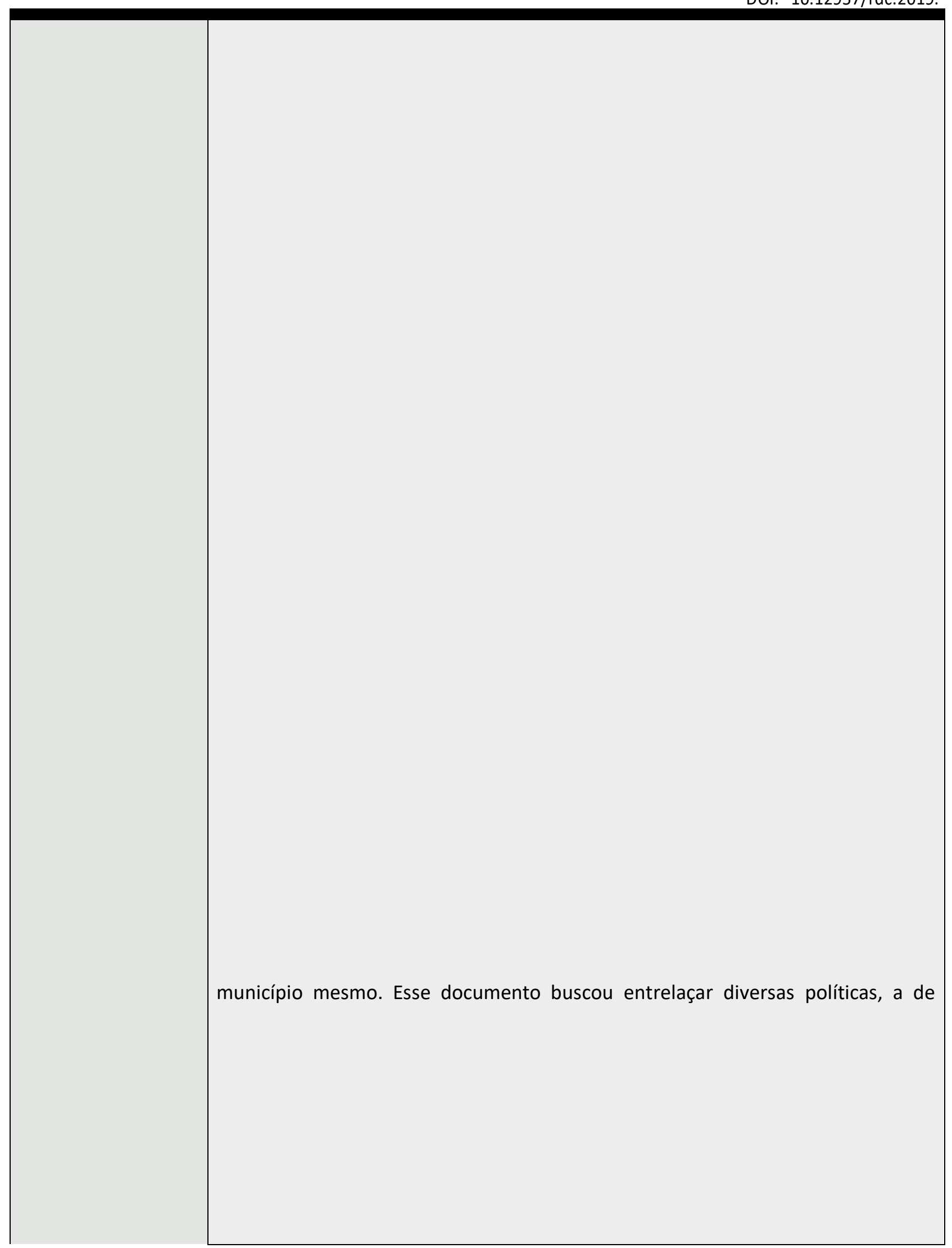




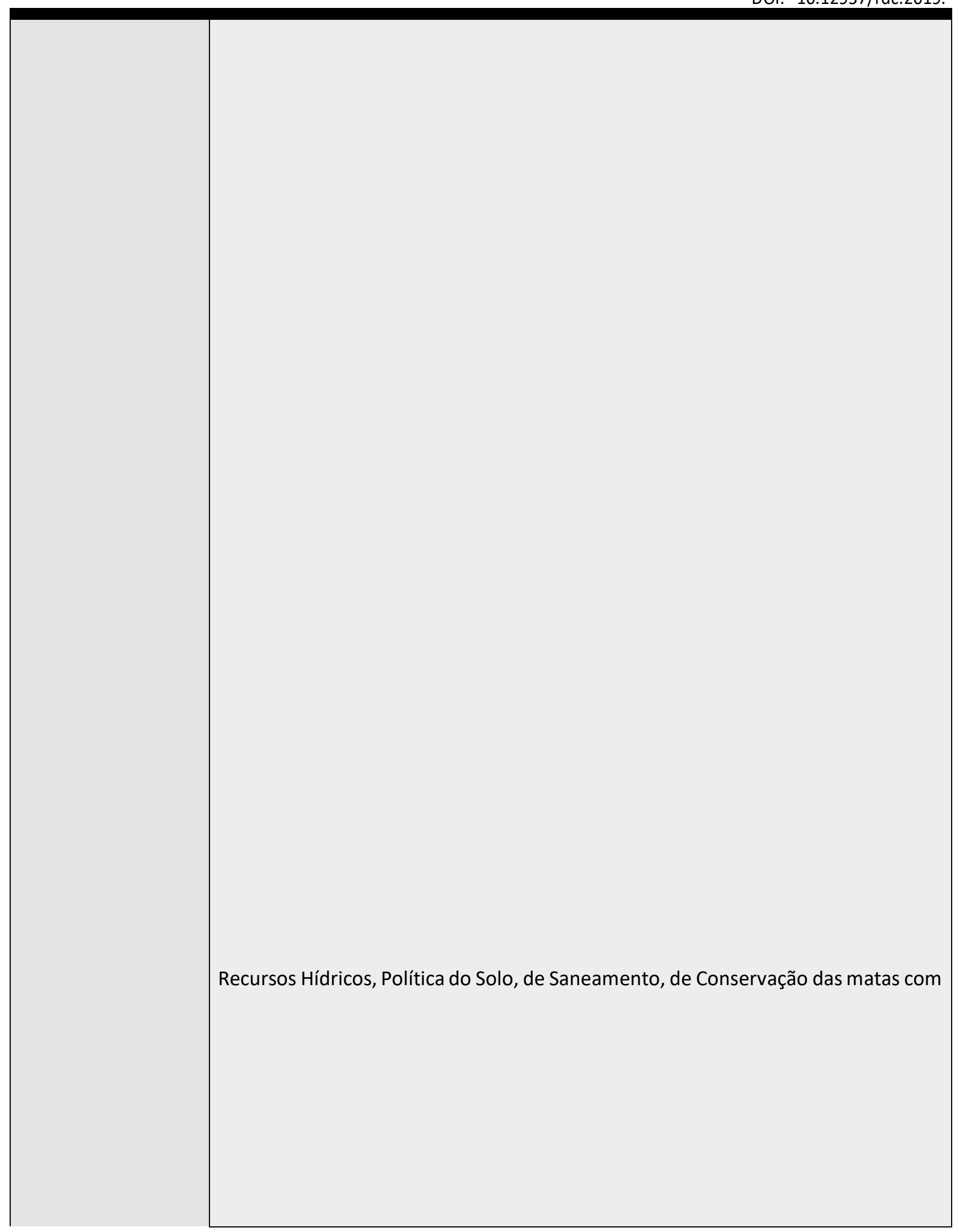




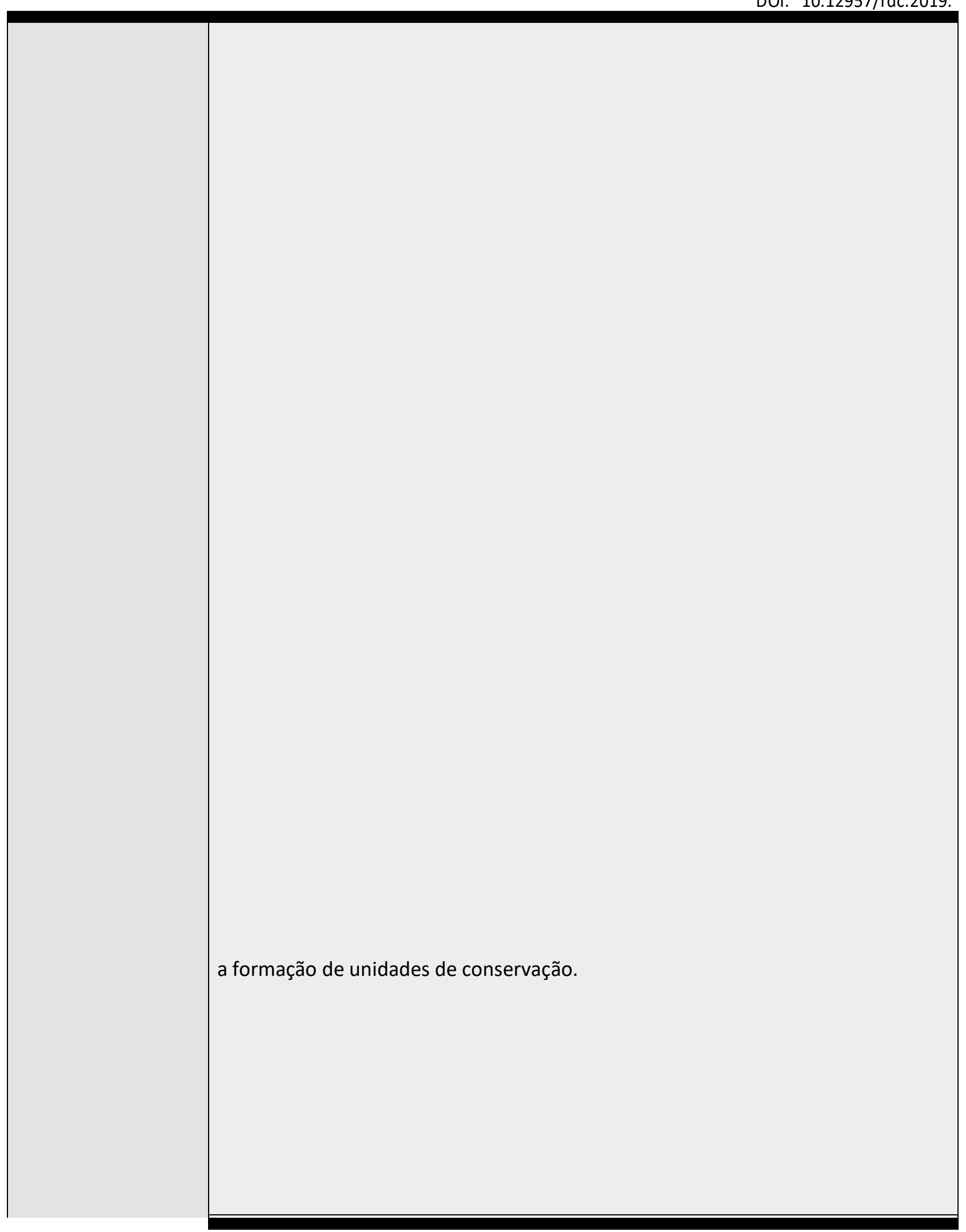




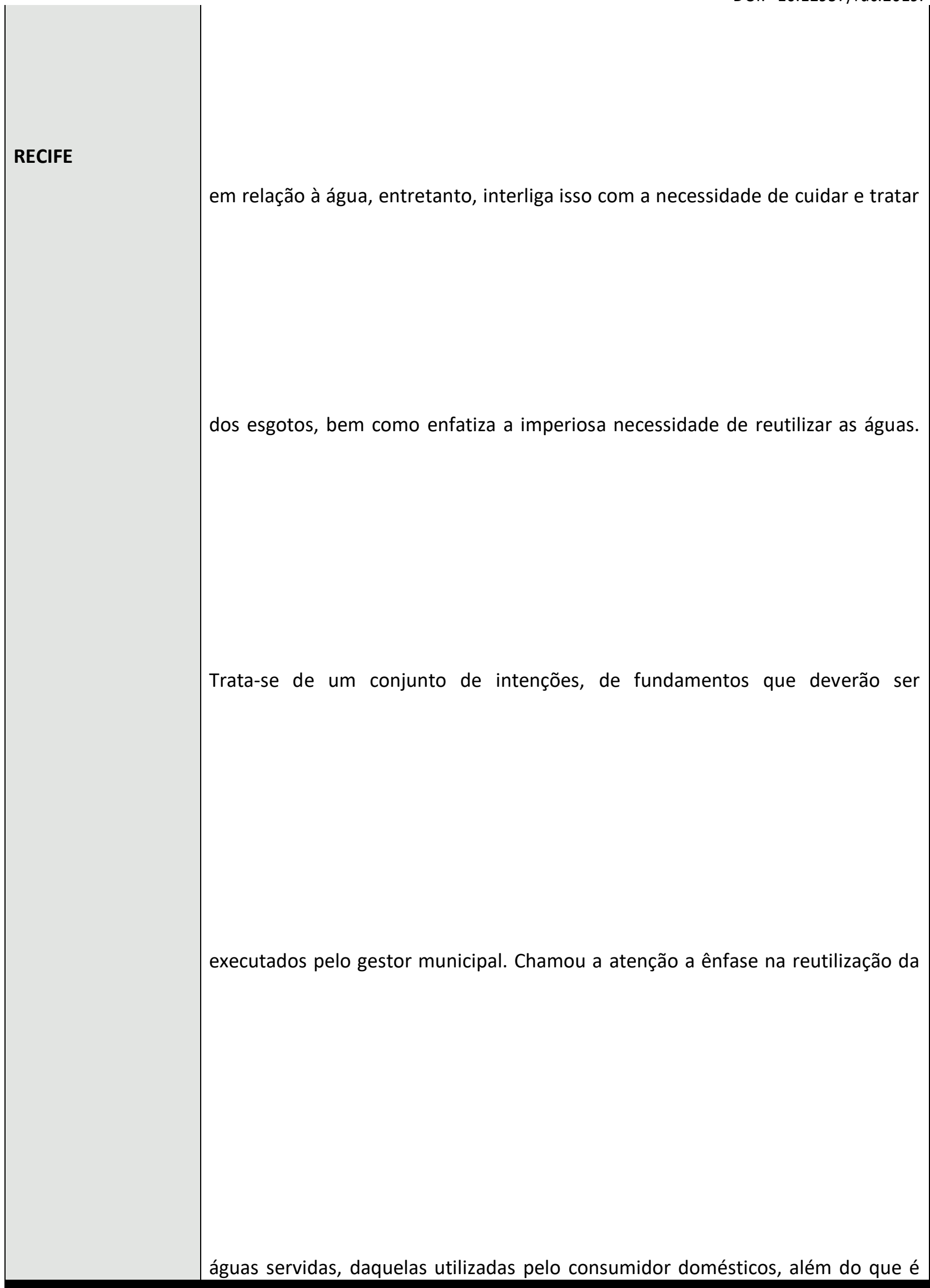

águas servidas, daquelas utilizadas pelo consumidor domésticos, além do que é 


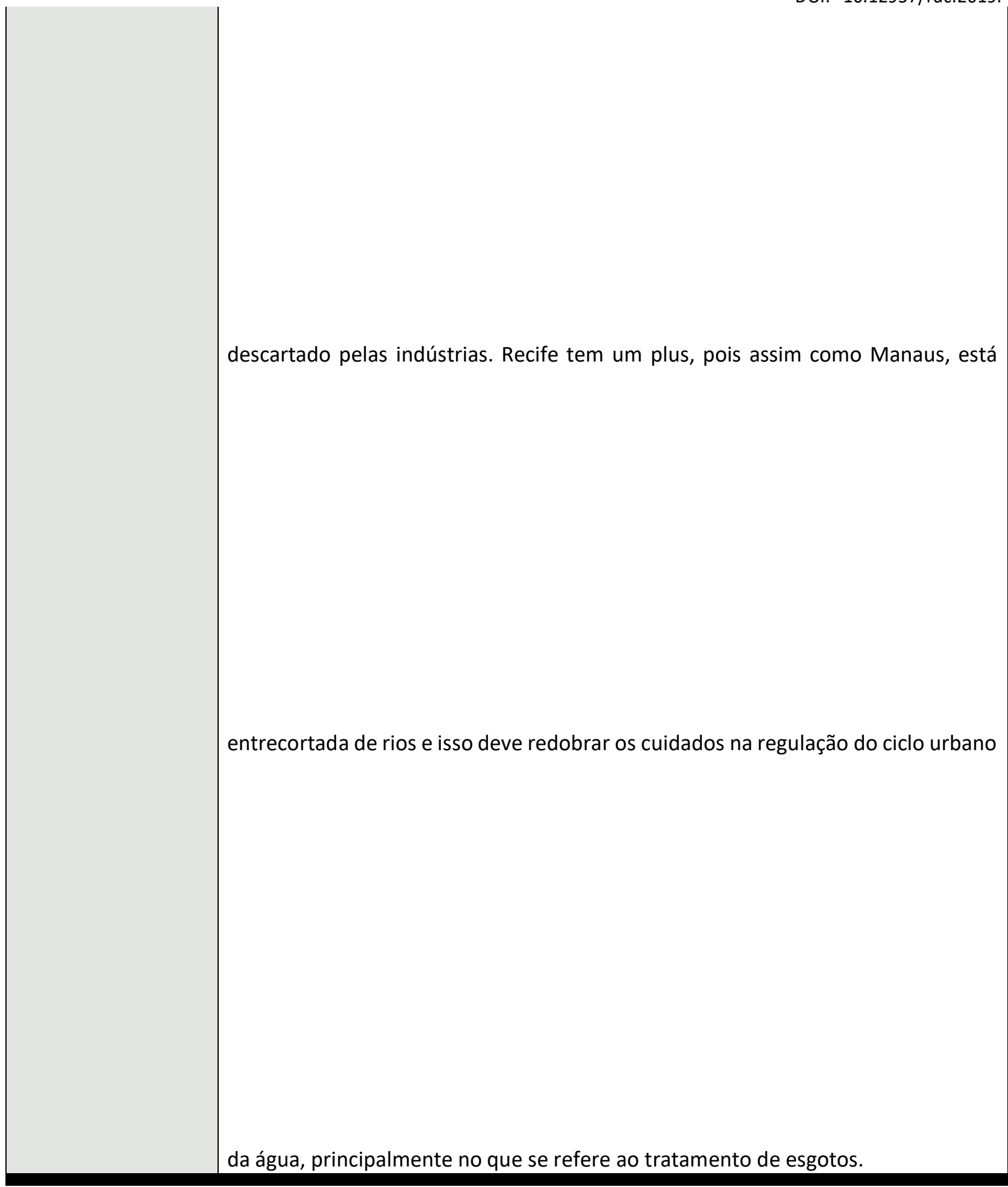




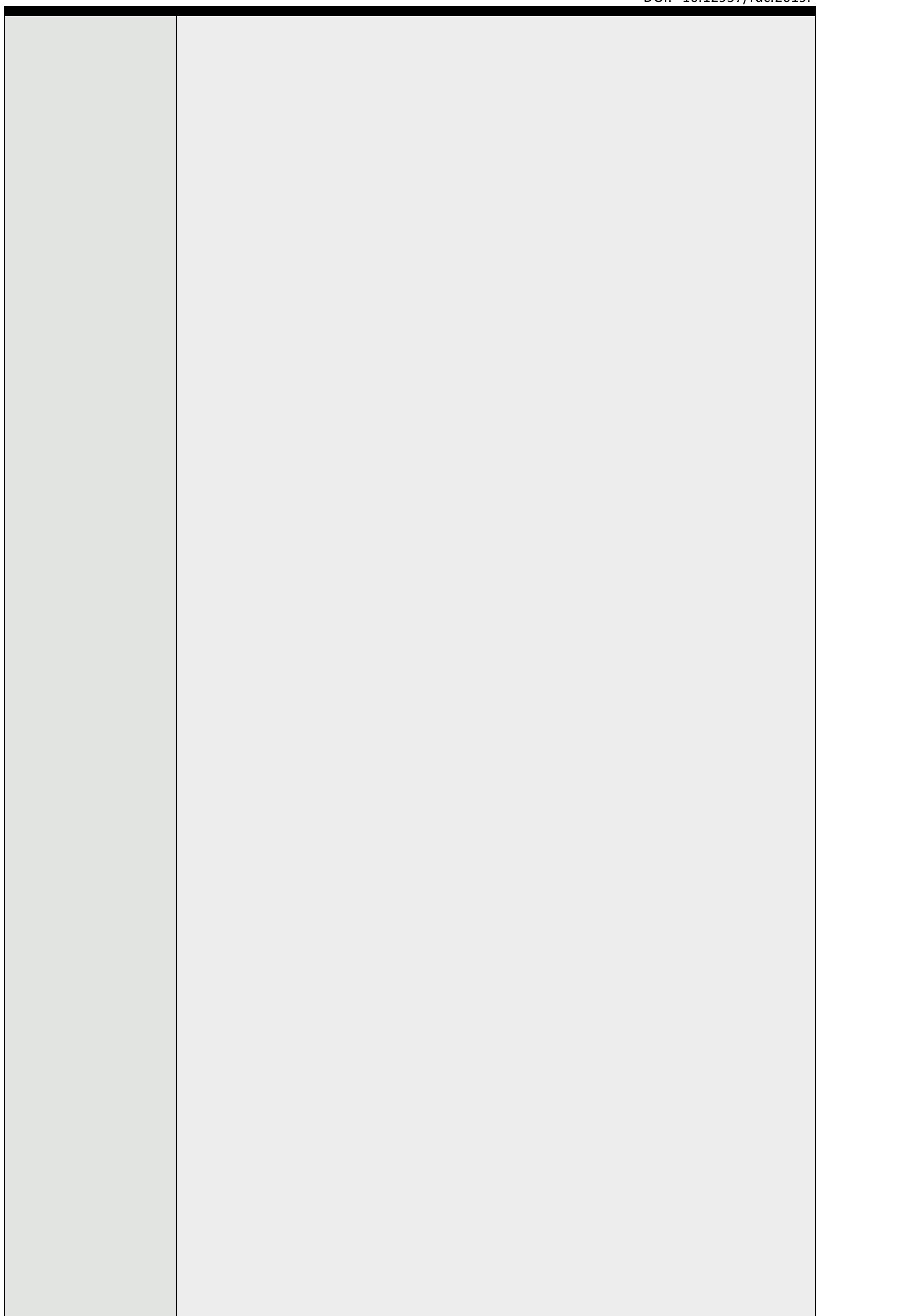




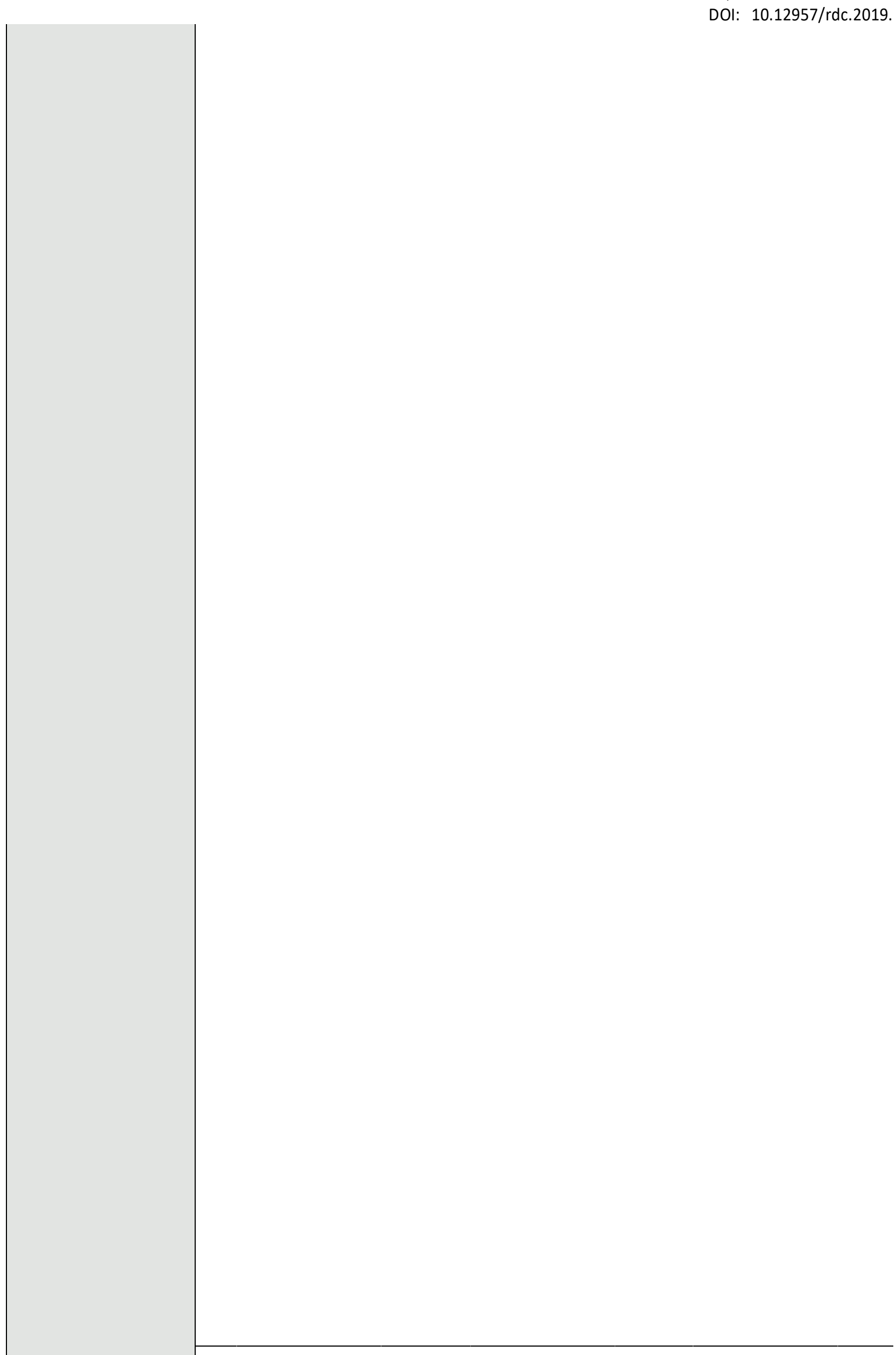




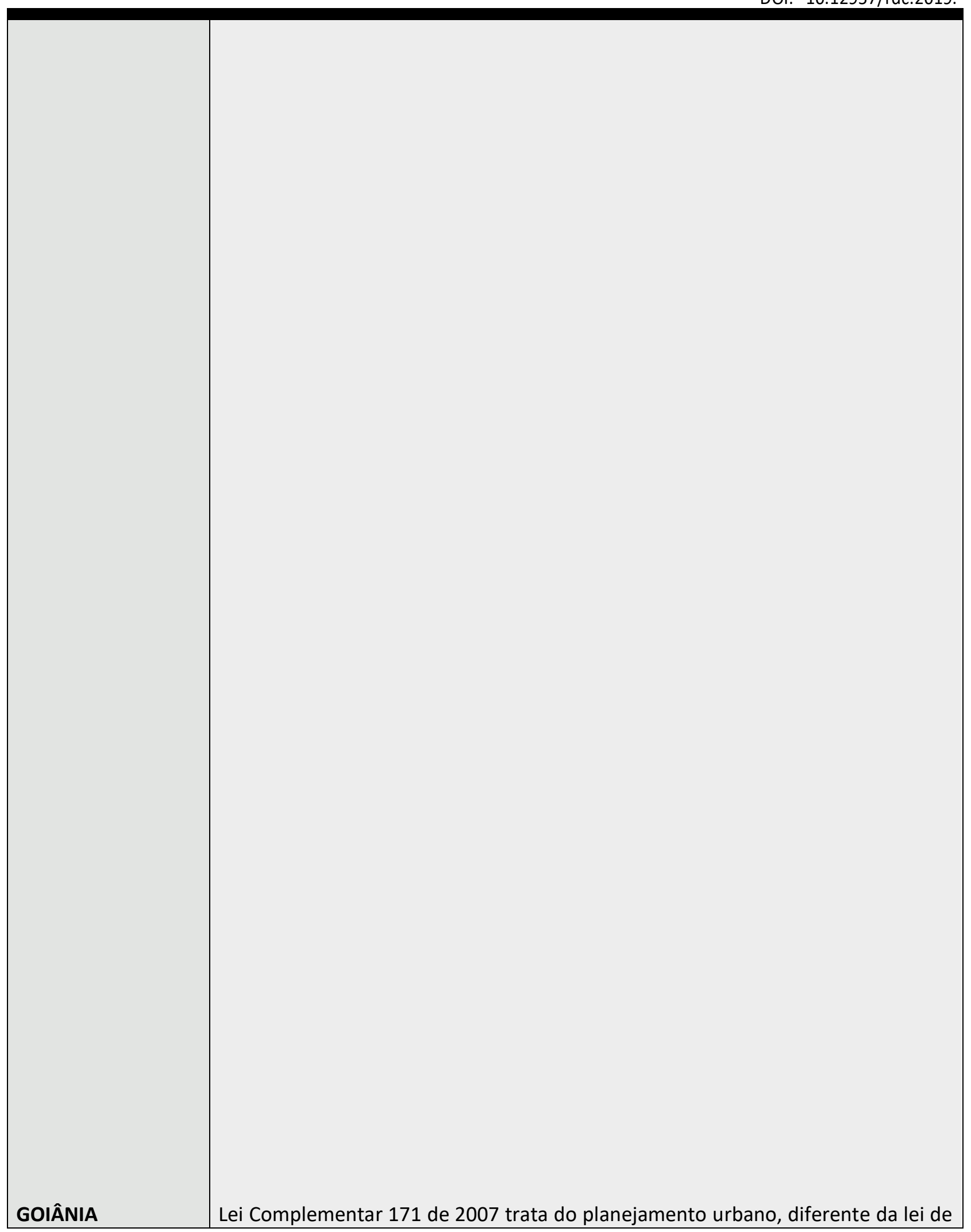




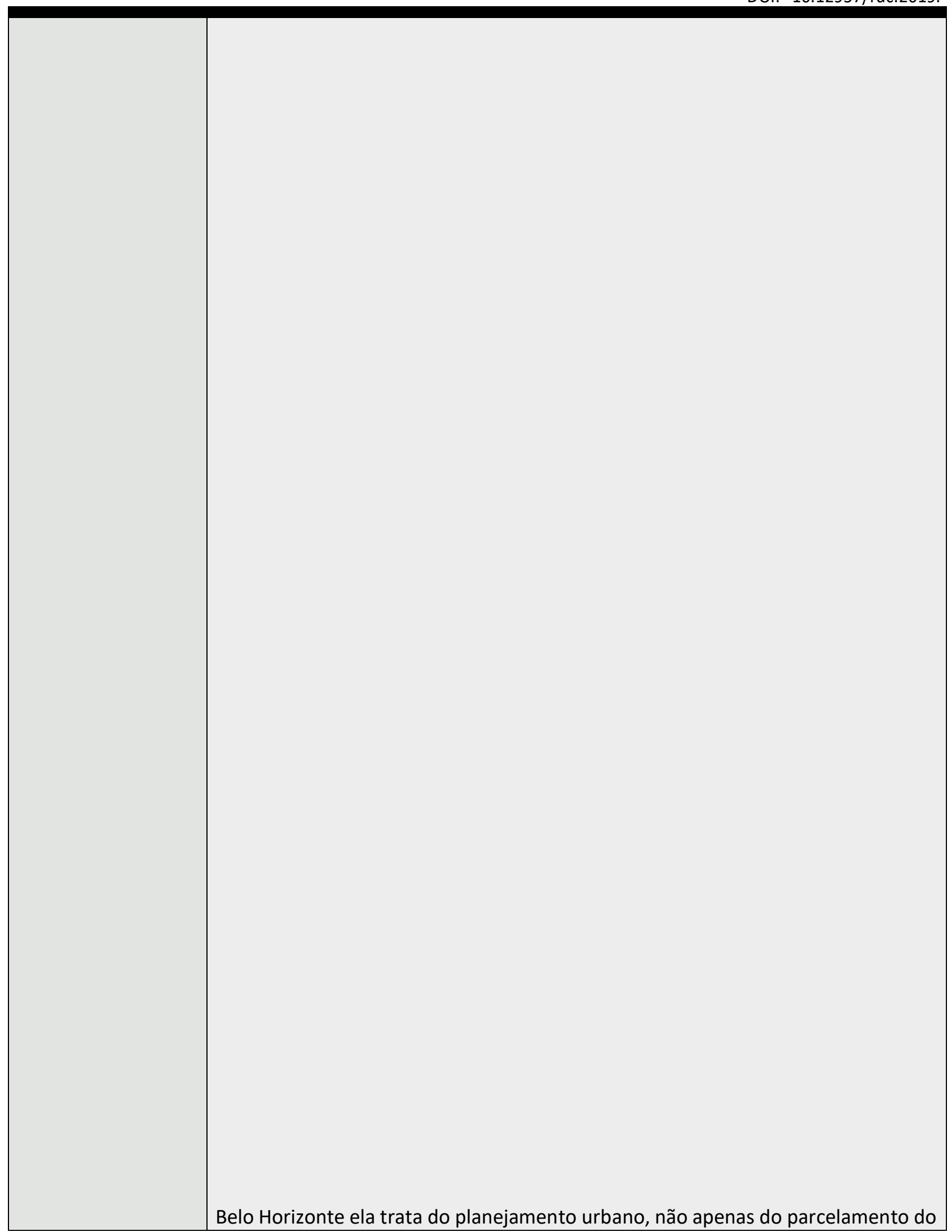




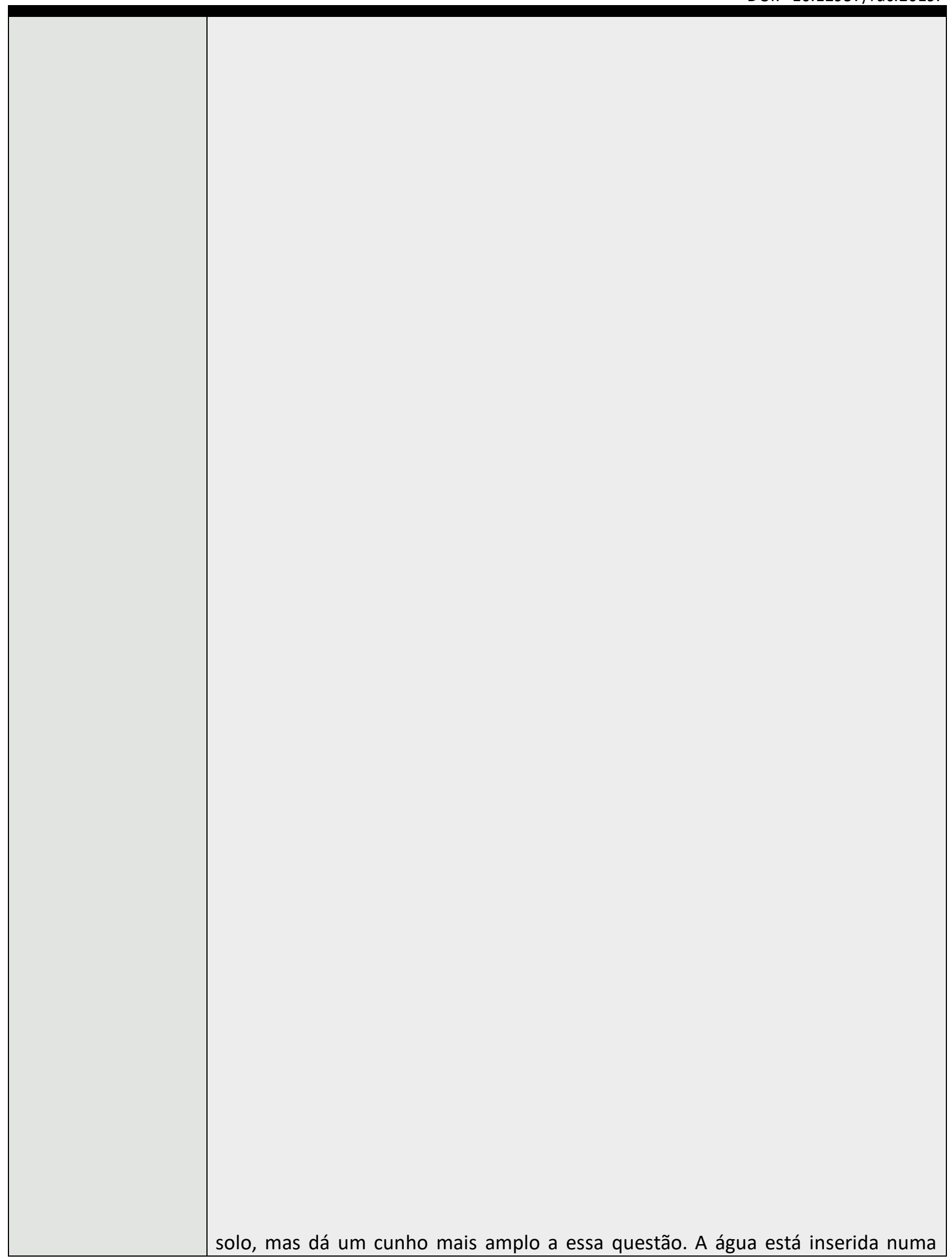




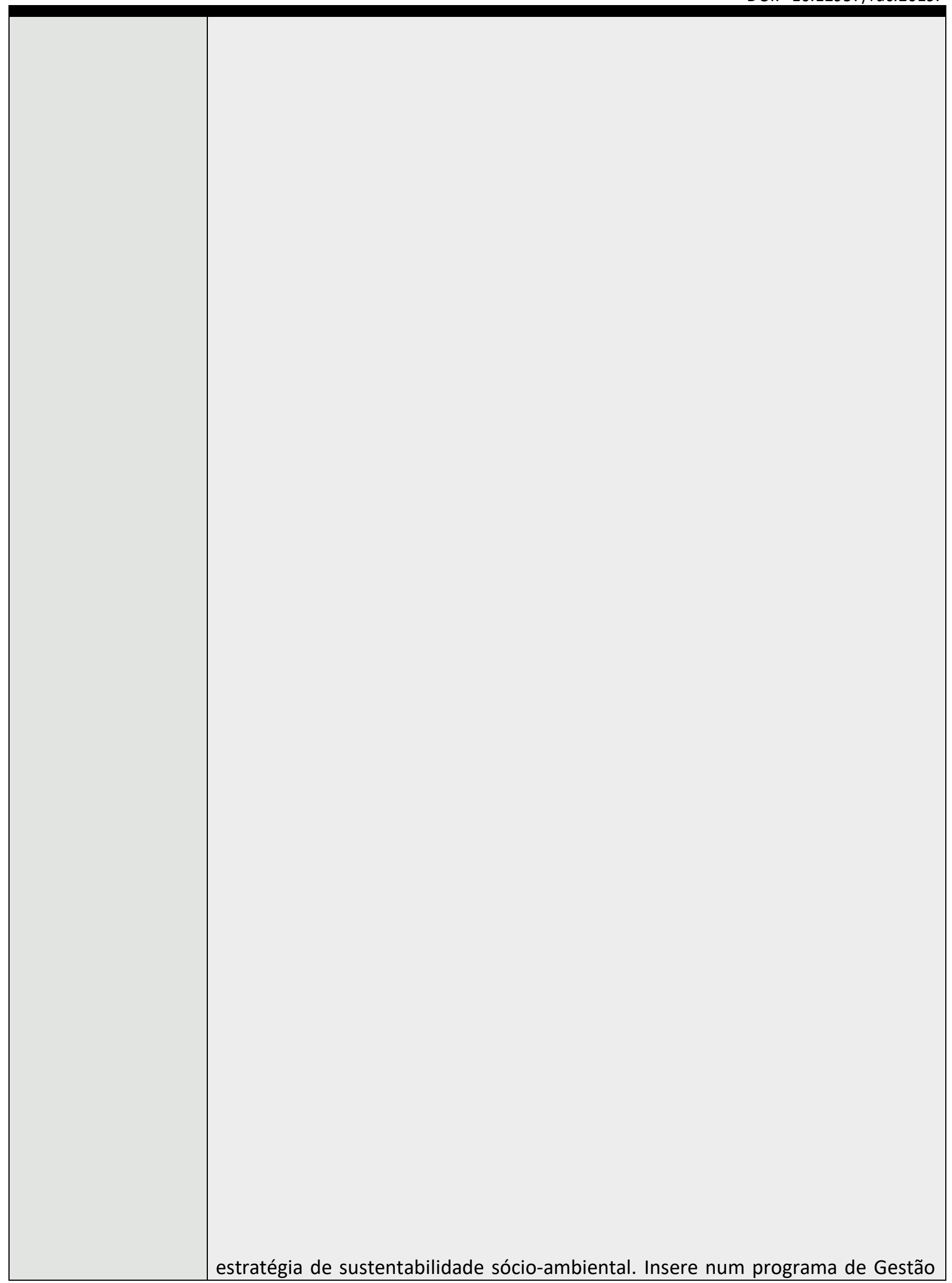




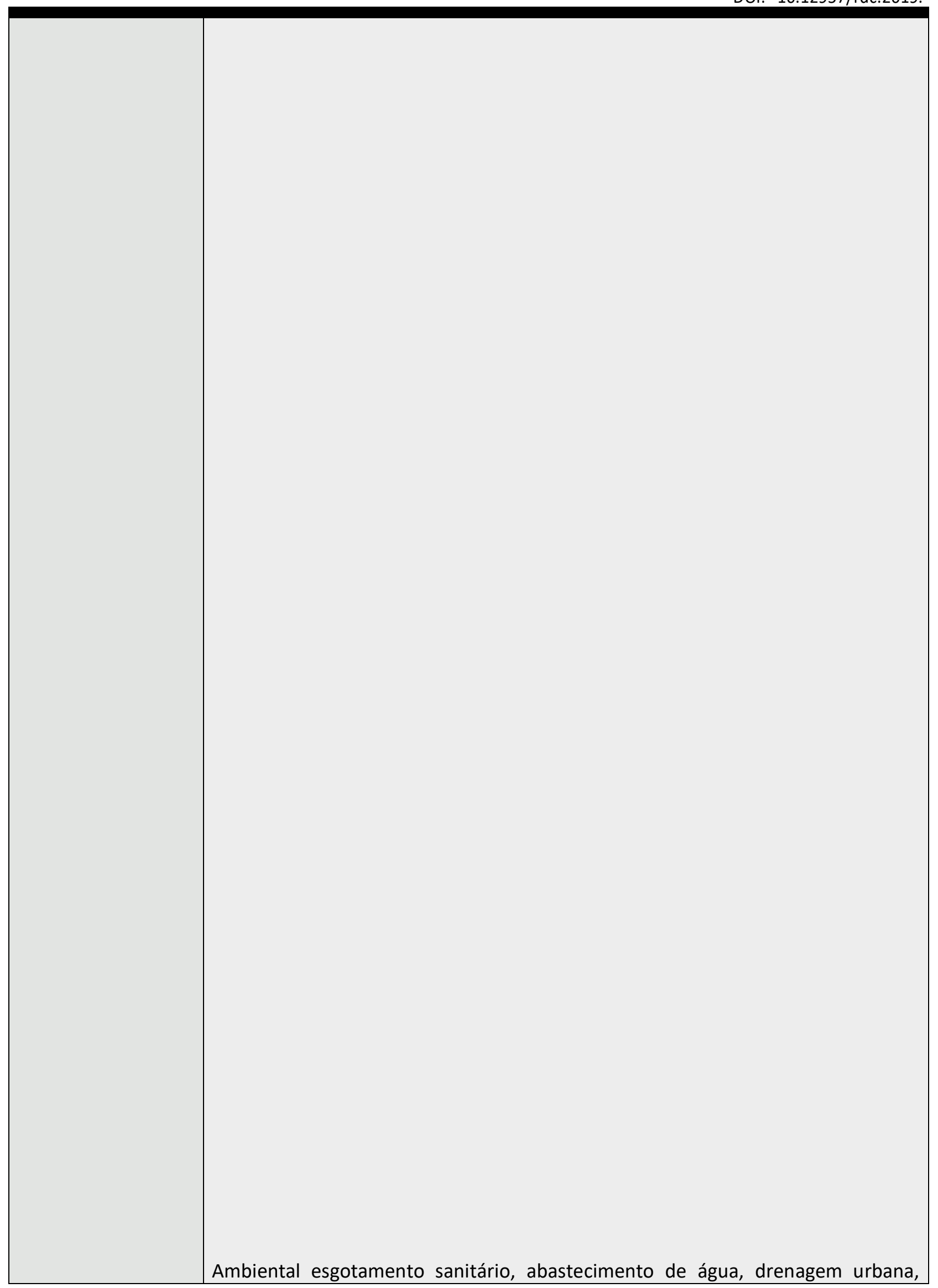




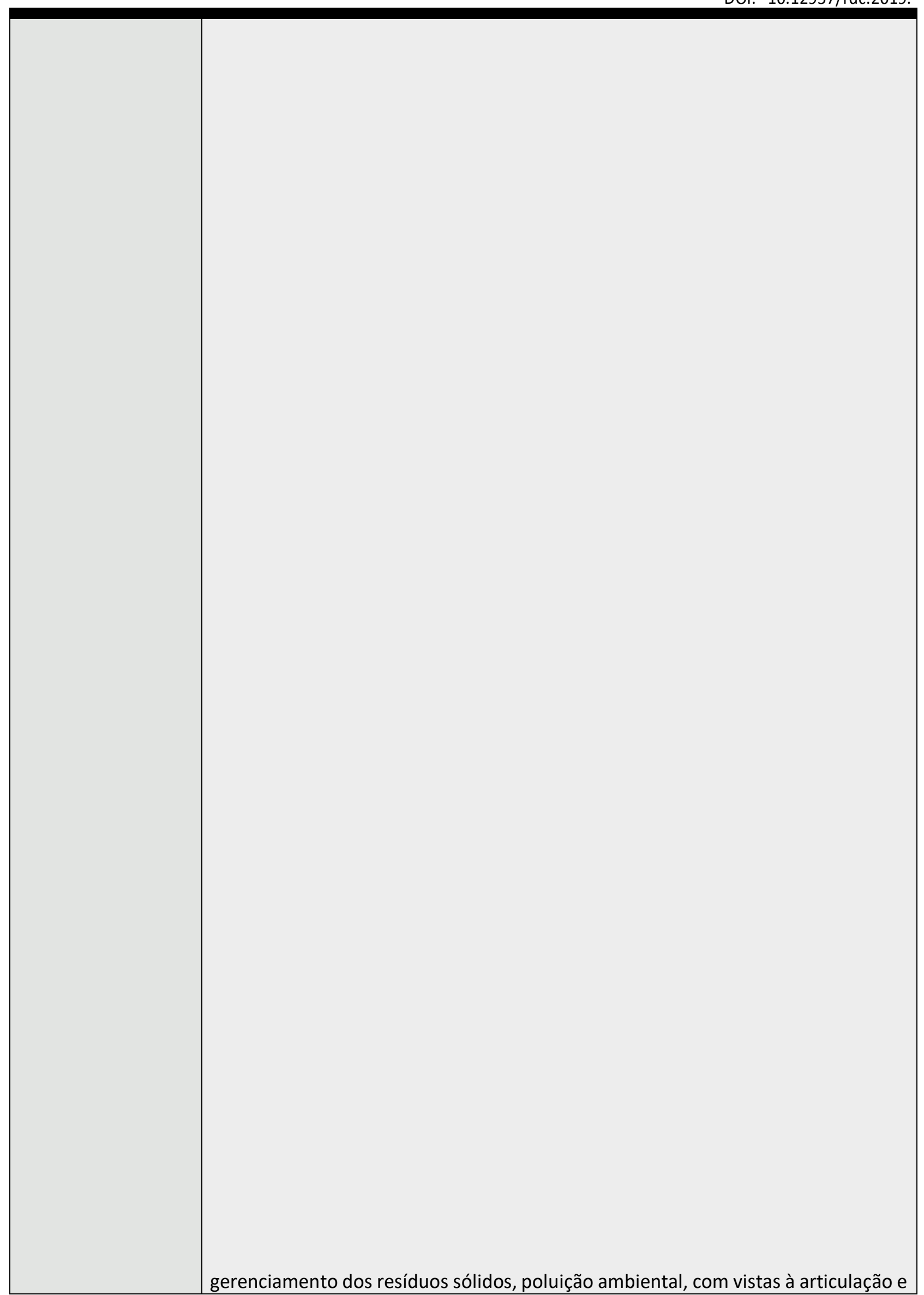




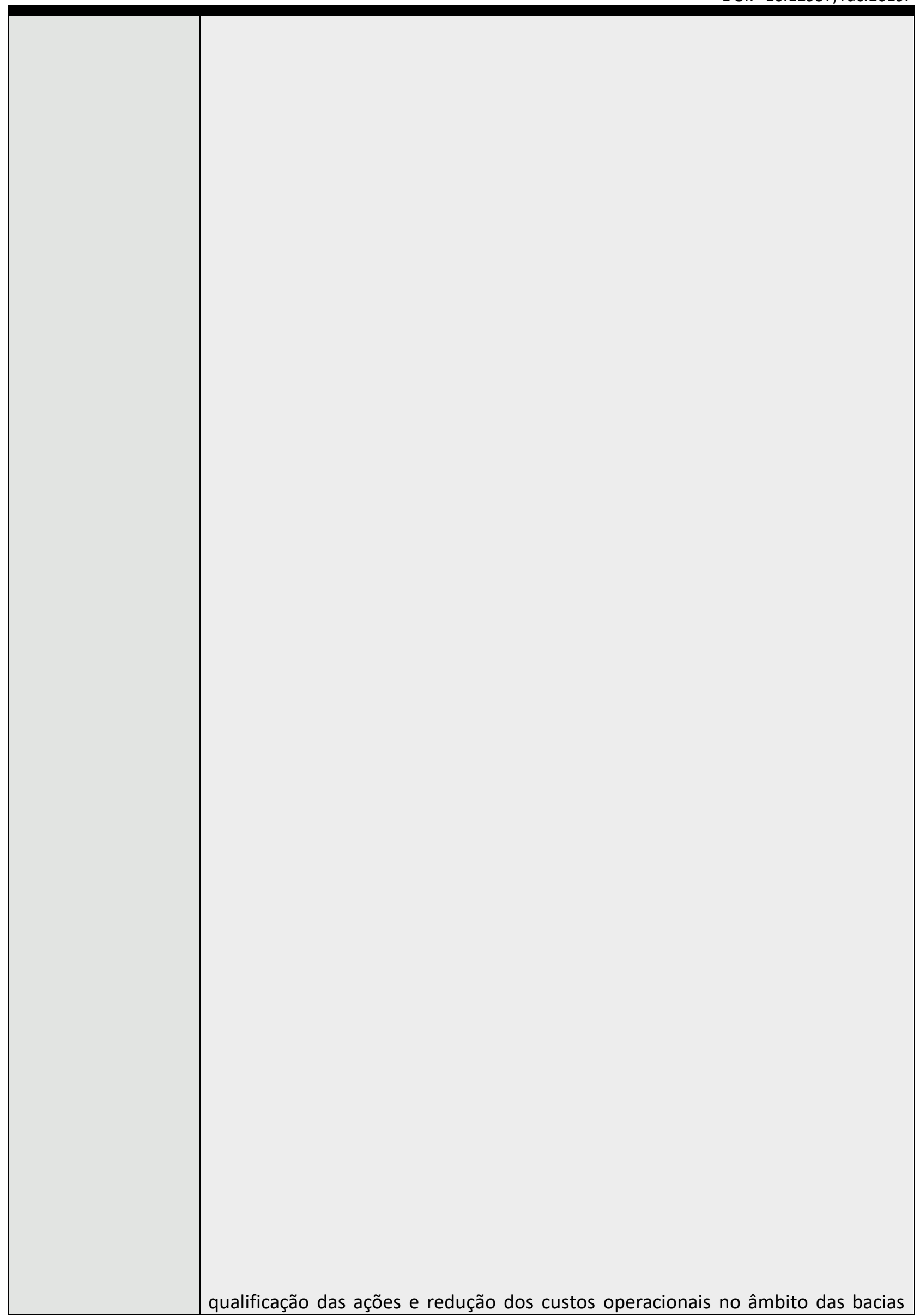




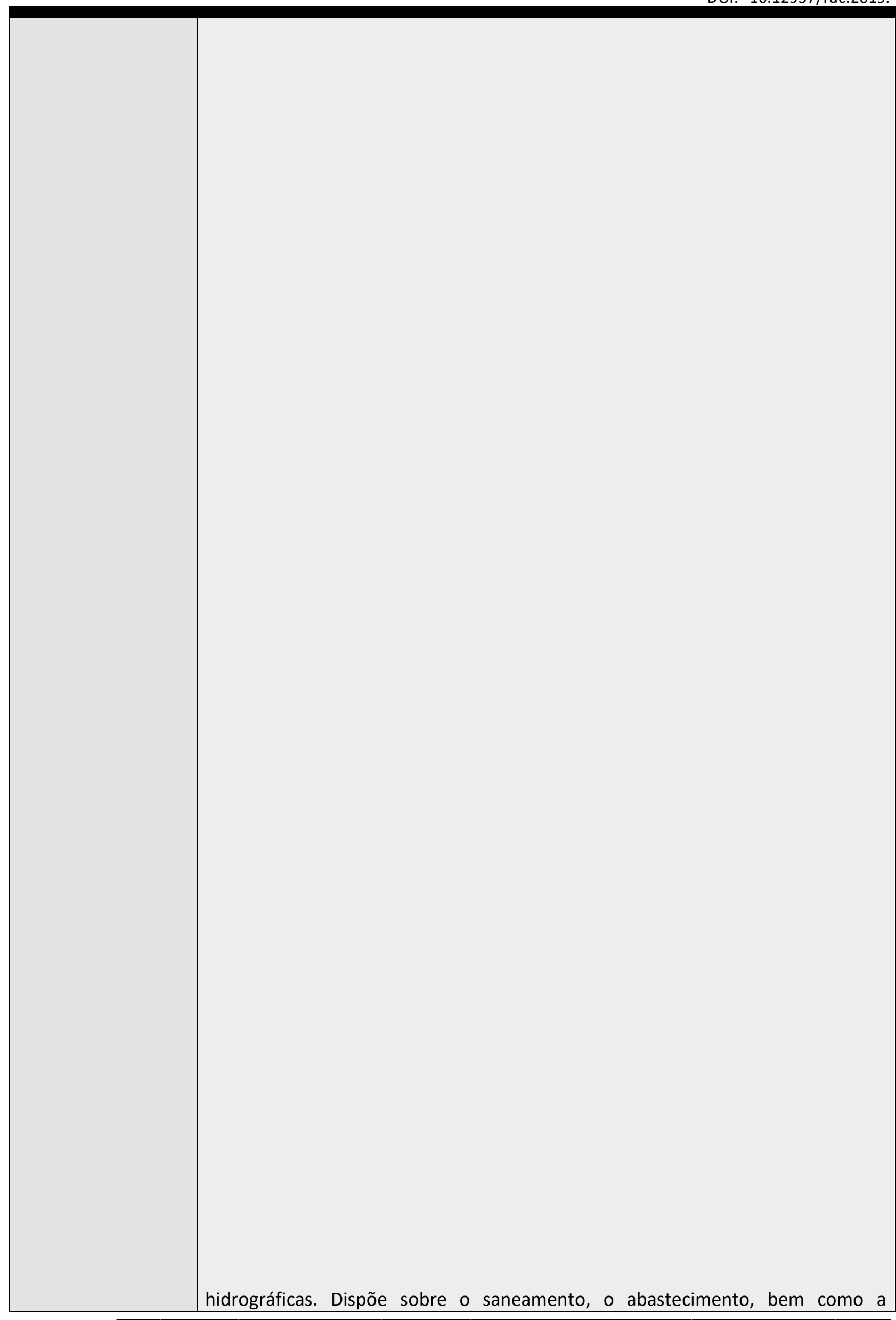




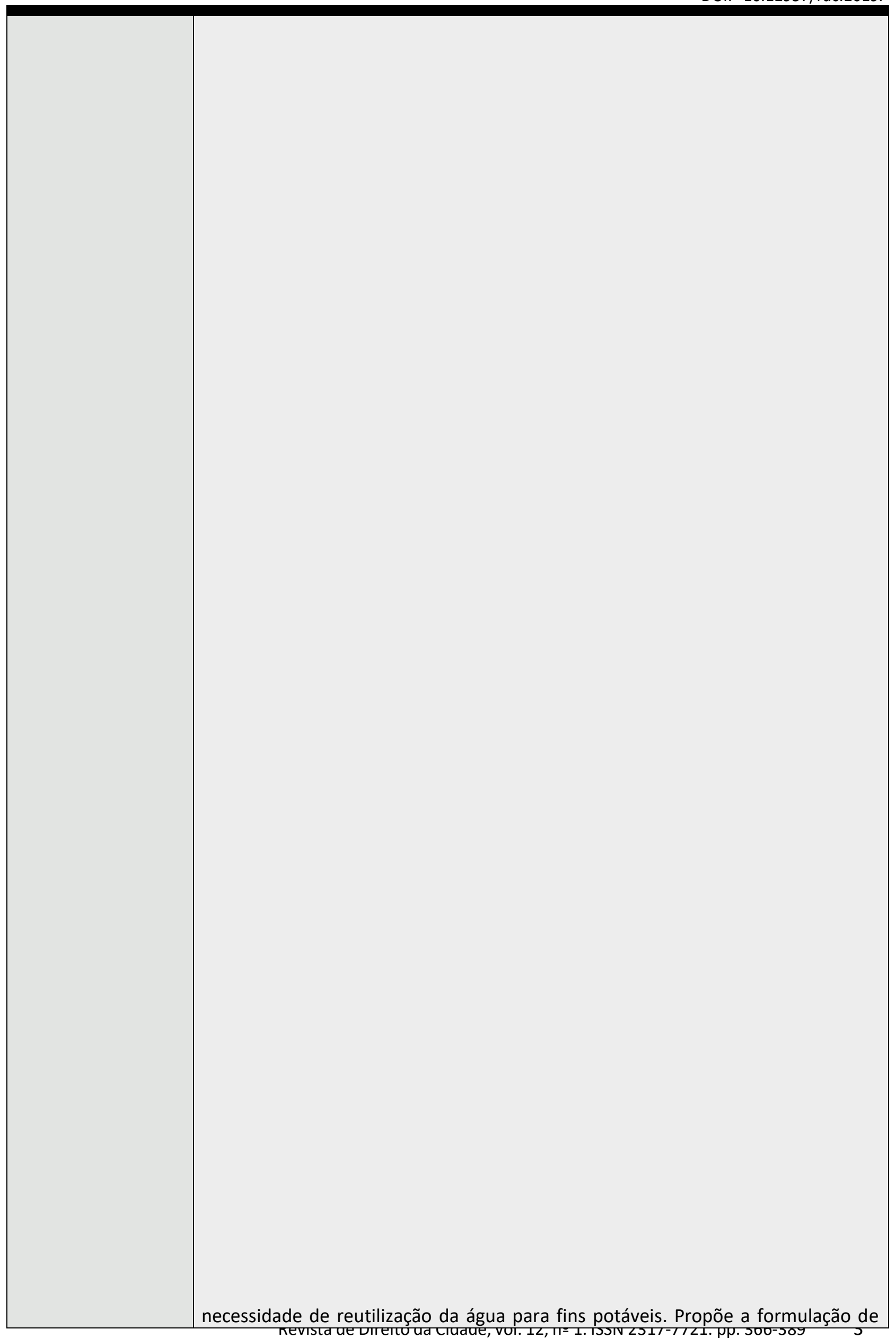




\begin{tabular}{|l|l|}
\hline PORTO ALEGRE & $\begin{array}{l}\text { instrumento legal que obrigue os proprietários de imóveis a instalar estruturas que } \\
\text { reaproveitem a água. A água e o saneamento estão incluídos numa estratégia sócio- } \\
\text { ambiental. }\end{array}$ \\
\hline $\begin{array}{l}\text { Lei Complementar n. } 434 \text { de } 1999 \text {, classificada como o Plano Diretor de } \\
\text { Desenvolvimento Urbano Ambiental, a água, o solo e o subsolo são considerados } \\
\text { patrimônio natural, o que possibilita a tutela jurídica dos mesmos pelo Poder } \\
\text { Público, o saneamento e a proteção estão agrupados para preservação do ciclo } \\
\text { urbano da água, embora não esteja implícito, não menciona nenhuma ação ou } \\
\text { princípio para a reutilização da água. }\end{array}$ \\
\hline
\end{tabular}

Fonte: Consulta realizada aos textos dos Planos Diretor disponibilizados nos sites dos respectivos poderes públicos.

Entretanto, buscando entender como esse comando constitucional está posto nos planos diretores foram escolhidos 7 município de grande porte, consideradas metrópoles, somando uma população de 22.355,380 (IBGE, 2017), o que representa quase $11 \%$ da população brasileira, além de serem regiões onde o ciclo urbano da água é bastante problemático. Como se verificou no quadro 3 , a coleta de dados nos planos diretores dessas metrópoles acentua a responsabilidade e a técnica necessárias para que essas possam preservar o ciclo urbano da água, considerando os obstáculos inerentes à atividade e ao aumento da demanda, a tutela jurídica do ciclo urbano da água, desde a captação até o descarte, após tratamento, quando possui, no solo ou num corpo de água é bastante complexa e demanda desses municípios equipamentos, pessoal, bem como atualização constante para racionalizar cada vez mais o uso e descarte da água, sendo necessários processos administrativos ágeis, transparentes, bem como um apoio jurídico atualizado com as questões de saneamento e meio ambiente.

O quadro 3 apresenta um pequeno extrato do que está posto nos planos diretores desses municípios apresentados, mas deve-se destacar o protagonismo que o saneamento e os recursos hídricos tomaram como tema importante nesses documentos. Alguns problemas que podem ser elencados em relação ao saneamento e aos recursos hídricos, que tem relação direta com o ciclo urbano da água:

1) Para o tratamento dos efluentes, pelo que se apresentou em termos de dados em 2017 no Atlas que a ANA publicou, há uma necessidade premente no aumento dos beneficiários do esgotamento sanitário, entretanto, é maior ainda quando se menciona a questão do tratamento da água e o que se observa é justamente uma concentração das estações de tratamento em regiões mais próximas das grandes cidades, cuja serviço ainda é deficitário, e o tratamento quase inexistente no interior do país (BRASIL, 2017); 
2) 65 milhões de pessoas no Brasil não possui rede coletora de esgotos (BRASIL, 2017), o que exige um cuidado maior por parte dos órgãos fiscalizadores no sentido de ingressar com ações de obrigação de fazer, para que sejam aplicados recursos nessas ações básicas;

3) O Brasil possui uma malha de água subterrânea muito extensa, o que é um privilégio, mas uma grande responsabilidade em relação aos municípios e estados para que haja fiscalização a contento no sentido de regular a perfuração muitas vezes indiscriminada de poços artesianos ou outras formas de captação (vide Mapa 1).

\section{Mapa 1 - representação da cobertura de água subterrânea no Brasil}

Fonte: CPRM -

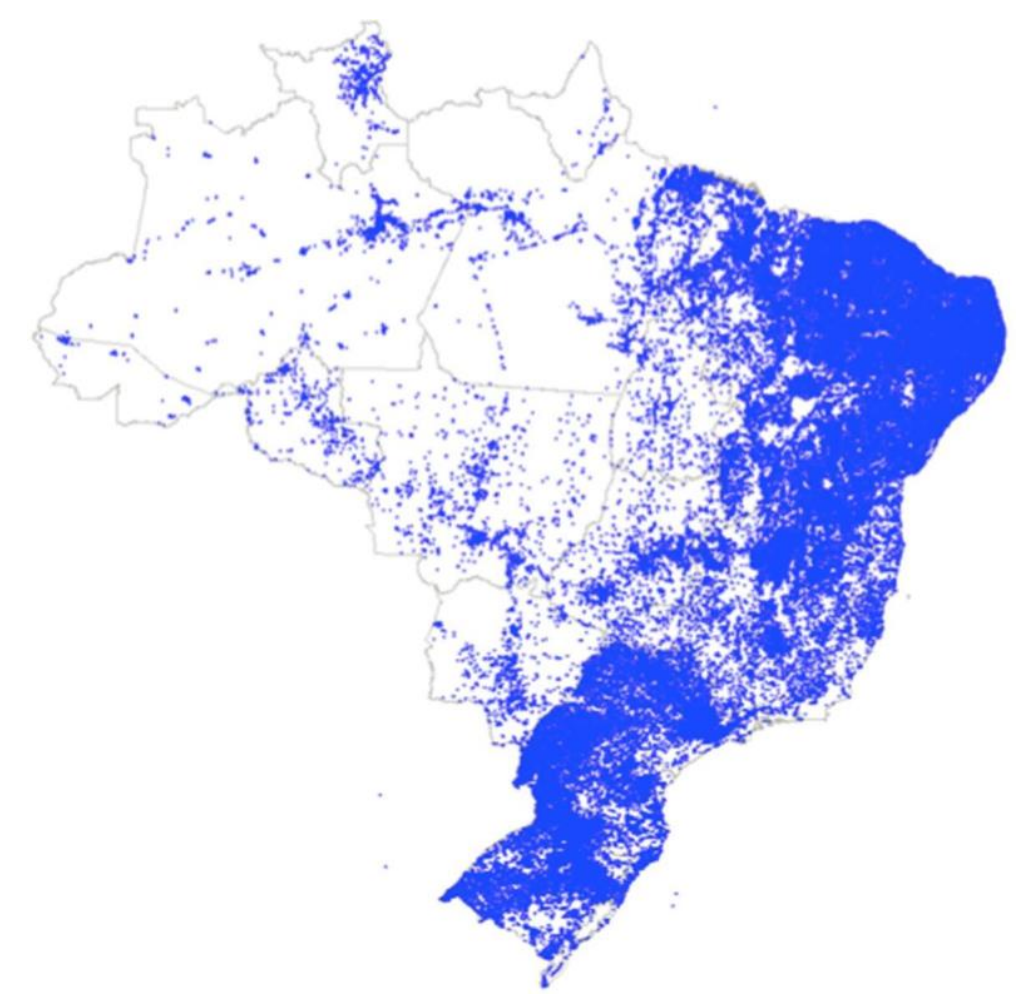

Geológico do Brasil - http://siagasweb.cprm.gov.br/layout/visualizar_mapa.php

Boa parte dessa faixa azul no Mapa 1 representa o ciclo urbano da água que tem seu destino certo para o subsolo, devendo os municípios protegerem as áreas de preservação permanente, facilitar o escoamento das água de chuva e outras águas, proteger a conservação do solo para uma maior absorção da água e consequente recarga. Portanto, não se trata de uma operação simples; 
4) Superar a má distribuição dos benefícios do saneamento básico no Brasil, como foi apresentado no Gráfico 1, faz parte dessa tutela jurídica do ciclo urbano da água, e quem deve fazer são os órgãos administrativos, que exercem o poder de polícia administrativa, bem como os órgãos que fiscalizam o cumprimento e o controle dos orçamentos como os Tribunais de Contas, além dos órgãos que atuam junto ao judiciário também como o Ministério Público e a Defensoria Pública;

5) Conforme planilha de dados do Ministério das Cidades, na Secretaria Nacional de Saneamento Básico, apenas 30\% dos municípios brasileiros possuem o Plano Municipal de Saneamento Básico, o que é muito sintomático e grave, uma vez que isso significa dizer que a maioria absoluta dos municípios brasileiros não possui o documento básico para preservação do ciclo urbano da água, suscitando o questionamento: o que está faltando? de quem é a falha? é um problema de gestão ou de tutela jurídica do ciclo urbano da água? No Mapa 2 tem a real situação no Brasil acerca da confecção dos Planos Municipais de Saneamento:

Mapa 2 -

Panorama dos

Municipais de

Saneamento

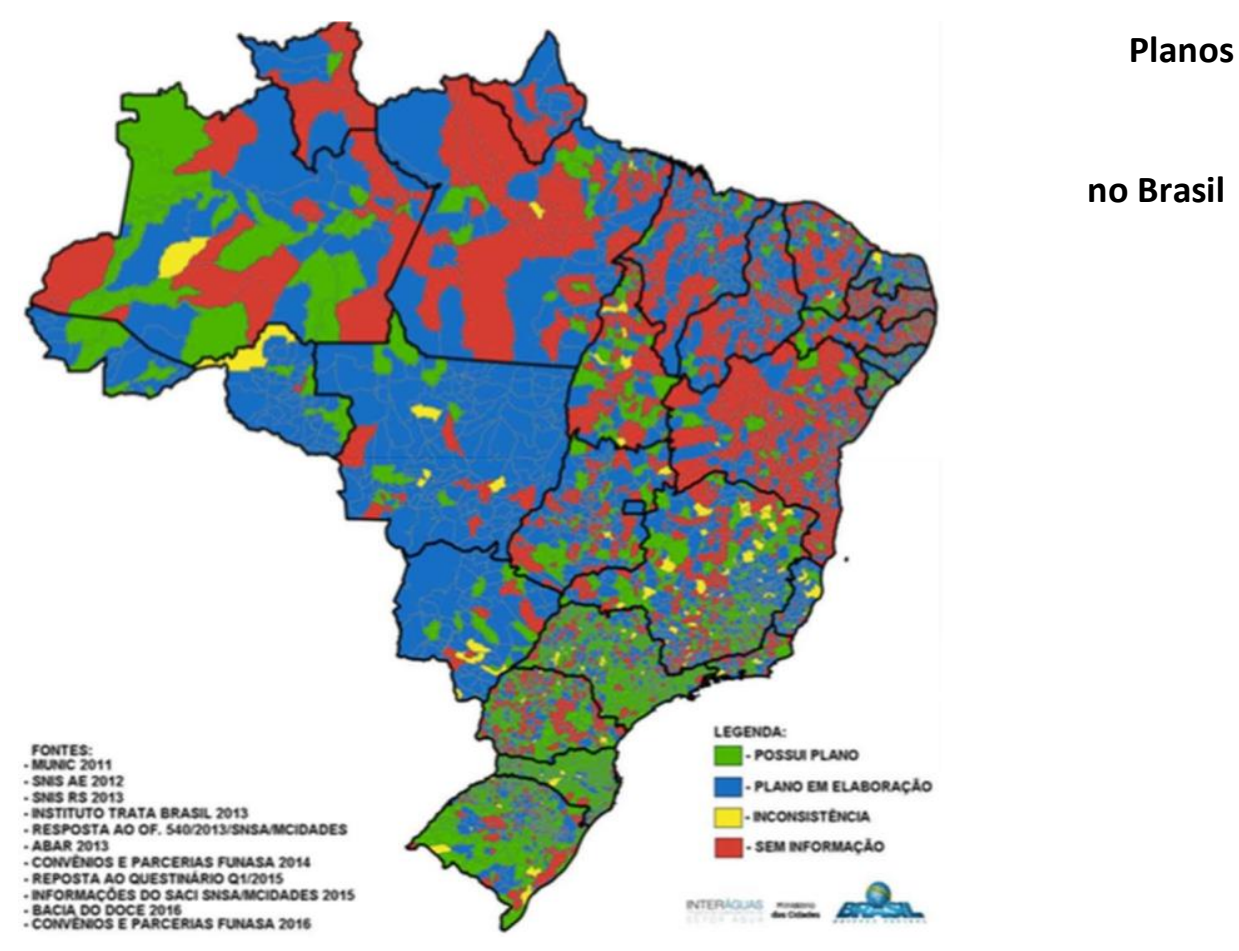

Fonte: Secretaria Nacional de Saneamento, Ministério das Cidades, 2017.

6) Assim como classificou e discorreu Silva et al (2017) o controle judicial das políticas públicas é uma realidade necessária, e no caso do saneamento, consequentemente o ciclo urbano da água, faz parte da Política Nacional de Desenvolvimento Urbano, coordenada no âmbito federal pelo 
Ministério das Cidades, podendo os conflitos originados das inexecuções de planos e planejamentos da gestão pública passar pelo crivo do judiciário.

Um problema, um desafio na verdade, é harmonizar as diversas esferas administrativas. No município ter-se-á a necessidade de analisar um sistema de normas, a partir do Plano Diretor, legislação estadual, tudo pautado sob a orientação da legislação federal que constitui a PNRH e a PNSB, além da Política Nacional de Resíduos Sólidos (PNRS). Assiste razão D'Isep (2010) quando se refere à água como sendo um propulsor de um peculiar diálogo de fontes, uma vez que não se trata de um bem isolado, mas de algo que se relaciona com ar, solo, fauna e flora, formando um microssistema hídrico normativo. Segundo D’Isep (2010) “a água se afigura como um verdadeiro catalisador de direitos, uma vez que é ela que concretizará o direito à vida, à dignidade, ao lazer, ao desenvolvimento, entre muitos outros". Daí tem-se diversos subsídios para a tutela do ciclo urbano da água. Desse modo, a tutela jurídica da água urbana e seu ciclo é fundamental para a preservação da vida e geração de desenvolvimento. Ademais, diante desse sistema jurídico complexo para a proteção do ciclo urbano da água é importante lembrar que podem existir diversos casos, num contexto de escassez de água, em que o sistema de proteção desse ciclo deve ser mais rígido, e outro de abundância de água, cujo sistema deve se comportar de maneira a catalisar o potencial de todo o excedente de água, tendo como diretriz a finitude desse recurso. Outro panorama é se na cidade passa um rio, ou não, a questão das águas subterrâneas, e D'Isep (2016, p. 354) arremata afirmando o seguinte:

proteger a água requer a construção da cartografia hidro jurídica, qual seja, a proteção do ciclo hidrológico em toda a sua extensão e formas, vez que, a água se revela plural (líquida, gasosa, vapor, água subterrânea, super ciais, ...). Daí o desafio jurídico de regrar a proteção da água em sua integralidade.

Nesse contexto o ciclo da água deve ocupar um espaço relevante diante da sua importância essencial e como foi demonstrado aqui, os planos diretores de algumas das cidades mais populosas do país já colocam-no num protagonismo relevante. Porém, assiste razão a D’Isep (2010; 2016) quando afirma a necessidade de, diante de questões relacionadas com a água nas cidades, abandonar o pensamento linear e adotar um pensamento complexo na tutela do ciclo urbano da água. Ainda é preciso equalizar esse processo de acesso à água advinda desse ciclo urbano que muitas vezes não chega a todos (BOELENS, 2008). Quando se pensa nessa complexidade é preocupante verificar que se tem um planeta coberto em sua maior parte por água, $70 \%$ da cobertura da Terra, cerca de $2,5 \%$ dessa água é doce, e apenas $1 \%$ é de fácil acesso (FAO, 2014). Isso torna o panorama pior, pois as cidades crescem e elas impactam diretamente nesse ciclo da água 
(PEREIRA et al, 2017). Para se ter uma ideia as cidades influenciam o ciclo hidrológico de várias maneiras, por exemplo: extraindo grandes quantidades de água de fontes superficiais e de águas subterrâneas; descarga de águas residuais não tratadas em corpos aquáticos; e ampliando as superfícies impermeáveis, dificultando a recarga de águas subterrâneas (PEREIRA; FREITAS, 2017). Portanto, para deixar claro, faz parte do escopo da regulação do ciclo urbano da água: a captação (reservatórios, barragens, rios, poços, entre outros), a drenagem da água das chuvas, a coleta do descarte residencial e industrial, o tratamento desse descarte ou resíduos, e a forma de descarte dessa água que foi usada, se será reutilizada ou mesmo lançada em corpos de água para retornar ao ciclo.

Prieur (2000) coloca que o meio ambiente em sua faceta científica apresenta incertezas que são encobertas pelas supostas certezas jurídicas, que poderiam ser traduzidas nessas normas aqui mostrada no quadro 4 como sendo o produto da tentativa de se dar uma segurança jurídica num contexto de pós-modernidade, de uma sociedade reflexiva e de risco, na qual a efemeridade é quem acaba regendo as vidas, o que torna a regulação através do direito ambiental mais exigente e, mesmo assim, imprecisa.

\section{CONSIDERAÇÕES FINAIS}

No presente artigo teve-se a pretensão de estabelecer parâmetros para se pensar a tutela jurídica do ciclo urbano da água e, dessa forma, chega-se a um ponto que o jurista, ou mesmo o gestor público, terá que possuir um olhar menos linear e mais complexo do fluxo da água do meio urbano, desde a captação, até o descarte das águas, e essa complexidade aumenta, certamente, proporcionalmente à extensão do seu perímetro urbano.

Demonstrou-se relevante ser levado em consideração numa Política de Desenvolvimento Urbano um olhar problematizador, uma vez que a distribuição da água passa por relações de poder e tem sido impactada diretamente pela diferenciação de classes sociais. A tutela jurídica do ciclo urbano da água passa pela compreensão da extensão dessa questão, pela existência de um microssistema hidronormativo, pela atuação contextualizada de órgãos de fiscalização nas esferas administrativas e judiciais, bem como pela participação dos diversos setores da sociedade na formulação de políticas, bem como no seu redirecionamento. Entende-se que além de um sistema normativo, deve-se ter órgãos preparados para atuar nessa questão hídrica dado sua importância 
estratégica da vida na Terra, já começa-se a verificar a atuação, por exemplo, do Ministério Público, que tem uma relevância considerável nessa tutela.

Porém, compreende-se que a tutela jurídica poderá ser a ultima ratio na medida em que as cidades possuam Planos Diretores efetivamente exequíveis, o que ainda está distante de acontecer, uma vez que faltam diversas cidades que não cumpriram esse requisito, tão pouco os plano locais de saneamento, mas como conduzir um avião sem instrumentos para navegar, é preciso ter planejamento urbano efetivamente executado. Isso é mais relevante ainda, quando se pensa nos recursos hídricos subterrâneos e superficiais que circulam pelas cidades e que, muitas vezes, não há fiscalização quanto ao uso dos mesmos, principalmente, um país com riqueza de água num contexto de escassez mundial.

\section{REFERÊNCIAS}

BRASIL. Ministério das Cidades. Secretaria Nacional de Saneamento Ambiental - SNSA. Sistema Nacional de Informações sobre Saneamento: Diagnóstico dos Serviços de Água e Esgotos - 2015. Brasília: SNSA/MCIDADES, 2017.

BRASIL. Ministério das Cidades. Secretaria Nacional de Saneamento Ambiental - SNSA. Sistema Nacional de Informações sobre Saneamento: Diagnóstico dos Serviços de Água e Esgotos - 2015. Brasília: SNSA/MCIDADES, 2017.

. Lei n. 6.938, de 31 de agosto de 1981. Brasília: Senado Federal, 1981.

Lei n. 10.257, 10 de julho de 2001. Brasília: Senado Federal, 2001.

. Resolução n. 420, de 30 de dezembro de 2009. Brasília: Conama, 2009.

Lei n. 9.433 de 8 de janeiro de 1997. Brasília: Senado Federal, 1997. Lei n. 11.445 de 5 de janeiro de 2007. Brasília: Senado Federal, 2007.

. Lei n. 9.985, de 18 de julho de 2000. Brasília: Senado Federal, 2000.

. Lei n. 12.651, de 25 de maio de 2012. Brasília: Senado Federal, 2012.

. Decreto-Lei n. 227, de 28 de fevereiro de 1967. Brasília: Presidência da República, 1967.

. Lei n. 12.305, de 2 de agosto de 2010. Brasil: Senado Federal, 2010.

. Decreto n. 4.297, de 10 de julho de 2002. Brasília: Presidência da República, 2002.

. Lei n. 9.605, de 12 de fevereiro de 1998. Brasília: Senado Federal, 1998.

. Lei n. 9.795, de 27 de abril de 1999. Brasília: Senado Federal, 1999.

. Resolução n. 303, de 20 de março de 2002. Brasília: Conama, 2002. 
. Resolução n. 335, de 3 de abril de 2003. Brasília: Conama, 2003.

. Resolução n. 396, 3 de abril de 2008. Brasília: Conama, 2008.

. Decreto-Lei n. 7.841, de 8 de agosto de 1945. Brasília; Presidência da República, 1945;

. Decreto n. 7.217, de 21 de junho de 2010. Brasília; Presidência, 2010.

BRITTO, A. L.; FORMIGA-JOHNSSON, R. M.;CARNEIRO, P. R. F. Abastecimento público e escassez hidrossocial na metrópole do Rio de Janeiro. In Ambiente \& Sociedade, São Paulo v. XIX, n. 1, p. 185$208 \mathrm{n}$ jan.-mar. 2016.

D`ISEP, C. F. M. Água Juridicamente sustentável. São Paulo: Revista dos Tribunais, 2010.

D ISEP, C. F. M. O rio e a cidade: o o diálogo jurídico entre o plano hídrico e o plano diretor. In Rev. Bras. Polít. Públicas (Online), Brasília, v. 6, no 3, 2016 p. 359-370.

ECHAID, J. El derecho humano al agua potable y los tratados de protección recíproca de inversiones. Tese (Doutorado en Derecho) - Facultad de Derecho, Universidad de Buenos Aires. Buenos Aires, p. 406, 2013.

FARIAS, T., CORREIA, A. F. Considerações a respeito da edificação urbana às margens de rios: a lei 12.651/2012 (novo código florestal) e a competência legislativa municipal. In FERREIRA, O. A. V. A., GRAU NETO, W. Temas polêmicos do Novo Código Florestal. São Paulo: Migalhas, 2016.

IBGE. Síntese de indicadores sociais : uma análise das condições de vida da população brasileira : 2017 / IBGE, Coordenação de População e Indicadores Sociais. Rio de Janeiro : IBGE, 2017.

LEITE, J. R. M. (Coord.). Manual de Direito Ambiental. São Paulo: Saraiva, 2015.

NAZARETH, P. A. Planos diretores e instrumentos de gestão urbana e ambiental no Estado do Rio de Janeiro. In Rev. Serv. Público Brasília 69 (1) 211-240 jan/mar 2018.

PEREIRA, J. C.; FREITAS, M. R. Cities and Water Security in the Anthropocene: Research Challenges and Opportunities for International Relations In Contexto Internacional vol. 39(3) Sep/Dec 2017.

PENA-GUZMAN, C. A; PRATS, D.; MELGAREJO, J. El ciclo urbano del agua en Bogotá, Colombia: estado actual y desafíos para la sostenibilidad. In Tecnología y Ciencias del Agua, vol. VII, núm. 6, noviembre-diciembre de 2016, pp. 57-71.

PRIEUR, M. Incertitude juridique, incertitude scientifique et protection de l'environment. In PRIEUR, M. Incertitude juridique, incertitude scientifique. Limoges: Pulim, 2000, p. 9-15.

PUJOL, D. S.; MARCH, H. ¿Qué sostenibilidad hídrica? Una interpretación crítica del descenso reciente del consumo doméstico de agua en Barcelona. In WATERLAT-GOBACIT Network Working Papers Thematic Area Series SATCUASPE - TA3 - Urban Water Cycle and Essential Public Services Vol. 1 N. 2, 2014.

QUINTSLR, S.; BRITTO, A. L. Desigualdades no acesso à agua e ao saneamento: impasses da política pública na metrópole fluminense. In WATERLAT-GOBACIT Network Working Papers Thematic Area Series SATCUASPE - TA3 - Urban Water Cycle and Essential Public Services - Vol. 1 N2, 2014.

SILVA, J. I. A. O.; CUNHA, B. P. da; GOMES, I. R. F D.. Políticas públicas ambientales: legalización y activismo judicial para el desarrollo sostenible. Revista de la Facultad de Derecho ( $2^{\circ}$ época), [S.I.], n. 42, p. 161-187, jun. 2017. ISSN 2301-0665. Disponible en:

$<$ http://revista.fder.edu.uy/index.php/rfd/article/view/574>. Fecha de acceso: 15 ene. 2018 doi:10.22187/rfd201718.

SWYNGEDOUW, E.; CASTRO, J. E. Agua urbana: una perspectiva ecológico-política. In WATERLATGOBACIT Network Working Papers Thematic Area Series SATCUASPE - TA3 - Urban Water Cycle and Essential Public Services-Vol. 3, N7, 2016. 
SWYNGEDOUW, E. Social Power and the Urbanisation of Water. Flows of Power. Oxford: Oxford University Press, 2004.

TUCCI, C. E. M. Águas urbanas. In Estudos Avançados 22 (63), 2008.

Trabalho enviado em 20 de janeiro de 2019

Aceito em 12 de abril de 2020 